\title{
Historyczne założenia obronne, architectura militaris i LiDAR. Wybrane zagadnienia metodyczne z zakresu zastosowania skanowania laserowego $\mathrm{w}$ detekcji i inwentaryzacji nowożytnych fortyfikacji
}

\author{
Rafał Zapłata
}

\section{Wprowadzenie}

Badania historycznych założeń obronnych, w tym fortyfikacji nowożytnych w Polsce, w ostatnich latach wzbogaciły się o nowe możliwości weryfikacji i rozpoznawania zabytków, co należy wiązać m.in. z technologią skanowania laserowego LiDAR (ang. Light Detection and Ranging), a zwłaszcza $\mathrm{z}$ lotniczym skanowaniem laserowym (ang. airborne laser scanning - ALS). Zarówno pomiary lotnicze, jak i naziemne (ang. terrestrial laser scanning - TLS) stanowią elementy procesu badawczego, które wyznaczają nowe możliwości analizy i inwentaryzacji tego typu obiektów zabytkowych. $\mathrm{Na}$ potencjał nowych metod zwraca uwagę pojawiająca się coraz częściej literatura przedmiotu, która uwagę skupia przede wszystkim na fortyfikacjach stałych (z dobrze zachowanymi i czytelnymi elementami konstrukcyjnymi) $)^{1}$, bazując głównie na ogólnie znanych przetworzeniach i wizualizacjach geodanych typu cieniowanie zboczy (ang. hill-shading). Warto zatem podkreślić również możliwości skanowania laserowego w odniesieniu do fortyfikacji polowych, a także zniszczonych, zniwelowanych i słabo czytelnych elementów historycznych obiektów militarnych. W zakresie rozwoju metodyki badawczej na

\footnotetext{
* Praca naukowa finansowana w ramach programu Ministra Nauki i Szkolnictwa Wyższego pod nazwą „Narodowy Program Rozwoju Humanistyki" w latach 2012-2016. W tekście wykorzystano wizualizacje i przetworzenia danych (Twierdza Srebrna Góra) udostępnione przez MGGP Aero sp. $z$ 0.0.

1 M. Antoszewski, W. Ostrowski, Lotniczy skaning laserowy (projekt ISOK) w ochronie zespotów fortyfikacji nowszej, w: Fortyfikacje nowożytne w Polsce - badania, realizacje, projekty. Zagospodarowanie do wspótczesnych funkcji, red. L. Narębski, Toruń 2013; A. Borkowski i in., Wykorzystanie danych skaningu laserowego do modelowania 3D fortów obronnych na przykładzie Fortu Prusy w Nysie, „Architektura Krajobrazu”, 4, 2013, s. 30-41; D. Zawieska,
}

szczególną uwagę zasługuje potencjał nie tylko samych pomiarów oraz danych ALS, ale i sposobów ich przetwarzania oraz wizualizacji, które wprowadzają kolejny element $w$ rozpoznawaniu, interpretacji i inwentaryzacji nowożytnych założeń obronnych. Oddzielnym zagadnieniem jest zwrócenie uwagi na rosnące możliwości omawianej w tekście technologii, w szczególności na tzw. czwarty wymiar, a więc rejestrację i analizę intensywności odbicia powracającej wiązki lasera (ang. intensity). Zabytkową architekturę obronną - z uwagi na jej specyfikę, zwłaszcza elementy konstrukcyjne (w tym budulec), oraz zróżnicowany stan zachowania, funkcje czy też znaczenie - należy rozpatrywać przynajmniej na pograniczu kilku dyscyplin bezpośrednio związanych z tymi obiektami, a więc historii wojskowości, historii architektury, archeologii historycznej2, jak również innych dyscyplin, których metody nieinwazyjne, aplikowane do badań dziedzictwa kulturowego w ostatnich latach, znacząco poszerzają pola poznawcze. Do metod tych, cieszących się coraz większym zainteresowaniem środowisk badawczych, a zarazem wzbogacających perspektywy poznawcze, należą m.in. metody geofizyczne, a także technolo-

\footnotetext{
W. Ostrowski, M. Antoszewski, Wykorzystanie danych lotniczego skaningu laserowego w metodyce badawczej zespotów fortyfikacji nowszej w Polsce, „Archiwum Fotogrametrii, Kartografii i Teledetekcji”, 25, 2013, s. 303-314 (http://pttit.sgp.geodezja.org.pl/wydawnictwa /kazimierz-2013/27 Zawieska_0strowski Antoszewski 303314. pdf, dostęp: 31 grudnia 2014); W. Ostrowski, D. Zawieska, Airborne Laser Scanning and GIS Application in Protection of Cultural Landscape of Fortifications, „SGEM2014 Conference Proceedings”, 3, 2014, s. 429-436.

2 T.M. Nowak, Badania nad historią techniki wojennej w Polsce: stan i perspektywy rozwoju, „Kwartalnik Historii Nauki i Techniki”, 22/2, 1977, s. 295-310.
} 
gie teledetekcyjne, takie jak fotografia lotnicza, zobrazowania satelitarne, a także skanowanie laserowe (naziemne i zwłaszcza lotnicze).

Zasadniczym celem artykułu jest omówienie wybranych zagadnień metodycznych związanych $z$ badaniem i inwentaryzacją zabytkowych fortyfikacji w Polsce w oparciu o lotnicze skanowanie laserowe i wybrane przetworzenia danych przestrzennych. Pośrednim celem tekstu jest podkreślenie ( $w$ charakterze głosu $\mathrm{w}$ dyskusji) potencjału, jaki niosą ze sobą nowoczesne technologie teledetekcyjne w badaniach i ochronie dziedzictwa kulturowego, a zarazem zwrócenie uwagi na kilka istotnych zagadnień związanych z jakością danych, ich przetwarzaniem, analizą i interpretacją oraz specyficznym środowiskiem występowania zabytków architektury militarnej, które w poniższym tekście wiązać będziemy przede wszystkim z terenami zalesionymi. Potencjał ALS i narzędzi geomatycznych zostanie zaprezentowany poprzez omówienie kilku wybranych przetworzeń i analizę przykładowych obiektów na terenach leśnych, którymi są fortyfikacje polowe wiązane $\mathrm{z}$ bitwą pod $\mathrm{Pa}$ kosławiem z 1915 r. oraz elementy zabytkowej Twierdzy Srebrna Góra.

Wielokrotnie podkreślany w literaturze przedmiotu potencjał dokładnych i nieinwazyjnych pomiarów, zwłaszcza ALS, bez wątpienia zyskuje coraz to szersze i nowsze zastosowanie, doprowadzając do kolejnych odkryć i weryfikacji obiektów zabytkowych ${ }^{3}$. Dla obszarów Polski nie bez znaczenia w odniesieniu do badań fortyfikacji pozostaje projekt ISOK (Informatyczny System Osłony Kraju - szerzej: http://www.isok. gov.pl/pl/), który dostarcza danych wprowadzających (w skali niemalże całego kraju) nową jakość prospekcji i inwentaryzacji obiektów zabytkowych. Dotychczasowa praktyka oraz zdobyte doświadczenie w zakresie stosowania danych ALS

\footnotetext{
3 Przykładowe publikacje: R.H. Bewley, S. Crutchley, C.A. Shell, New Light on an Ancient Landscape: Lidar Survey in the Stonehenge World Heritage Site, „Antiquity”, 79 (305), 2005, s. 636-647; A.F. Chase i in., Airborne LiDAR, Archaeology, and the Ancient Maya Landscape at Caracol, Belize, „Journal of Archaeological Science”, 38 (2), 2011, s. 387-398 (http:// www.caracol.org/include/files/chase/JASarticle.pdf, dostęp: 31 grudnia 2014); S. Crutchley, P. Crow, The Light Fantastic: Using Airborne Laser Scanning in Archaeological Survey, Swindon 2009 (http://www.english -heritage.org.uk/publications/light-fantastic/, dostęp: 31 grudnia 2014).
}

wskazują jednak, że po okresie pionierskich aplikacji omawianych metod warto zwrócić uwage na pewne ograniczenia pozyskiwanych danych, a zarazem wskazać kilka istotnych postulatów w zakresie wykorzystywania i poprawy dotychczasowych praktyk badawczych.

O ile zachowane i niejednokrotnie widoczne w terenie pozostałości zabytkowej architektury obronnej nie sprawiają problemów związanych z lokalizacją poszczególnych elementów fortyfikacji (ryc. 1), o tyle poza horyzontem poznawczym często pozostają obiekty i elementy całego założenia, które nie zachowały się do dzisiaj w tak czytelnej formie (ryc. 2, 4). Przykładem znanych i dobrze zachowanych oraz wyeksponowanych zabytków są m.in. obiekty militarne (np. twierdze) występujące na terenach wielu miast, jak np. Warszawa, Wrocław czy Nysa, a zarazem te znajdujące się poza przestrzenią miejską, często na terenach leśnych, jak np. Twierdza Srebrna Góra (ryc. 1-3). Drugą niejako kategorią nowożytnych obiektów fortyfikacyjnych są słabo czytelne, całkowicie zniwelowane lub też częściowo zachowujące własną formę krajobrazową pozostałości fortyfikacji, zwłaszcza polowych, które stanowią zasób o często nikłym zapisie archiwalnym. Tego typu relikty fortyfikacji mają obecnie szansę na rozpoznanie i zadokumentowanie poprzez zastosowanie m.in. technologii lotniczego skanowania laserowego wraz z wykorzystaniem wielu narzędzi geoinformacyjnych, które wpisują się w kreśloną od lat politykę konserwatorsko-badawczą architectura militaris ${ }^{4}$.

\section{Zabytkowe założenia obronne}

Fortyfikacje nowożytne charakteryzuje zmienna w czasie różnorodność form, a zarazem złożoność, na którą składają się zasadniczo elementy trwałe (stałe) o konstrukcji murowanej,

\footnotetext{
4 M.in.: J. Bogdanowski, Krajobraz warowny XIXIXX w. Dzieje i rewaloryzacja, Kraków 1993; Fortyfikacja, t. 6: Ochrona i konserwacja architektury obronnej, red. M. Lewicka-Cempa, Warszawa 1999; P. Molski, Cechy fortyfikacji nowszej a metody waloryzacji konserwatorskiej, w: Prace naukowe / Wydział Architektury Politechniki Warszawskiej, t. 2, Warszawa 2002; tenże, Ochrona i zagospodarowanie wybranych zespołów fortyfikacji nowszej w Polsce, Warszawa 2007; Fortyfikacje nowożytne.
} 
drewnianej czy kamienno-ziemnej oraz polowe (nietrwałe), zazwyczaj drewniano-ziemne, rzadziej murowane ${ }^{5}$.

Szereg znanych obiektów architektury militarnej - fortyfikacji trwałych znajdujących się zarówno na terenach otwartych, miejskich (np. Fort Bielany w Warszawie - ryc. 2) czy rolniczych, jak i na zalesionych (np. Twierdza Srebrna Góra) charakteryzuje na tyle dobry stan zachowania, że ich rozpoznanie i badanie nie stanowią większego problemu dla środowisk naukowo-
Kolejną grupę stanowią obiekty nieukończone, takie jak reduty, forty itp., po których pozostały jedynie znikome ślady, np. w postaci śladowo zachowanych deformacji terenowych (wysokościowych): wyniesień czy zagłębień będących pozostałością rozpoczętych budów, oraz wzmianki w materiale archiwalnym. Szereg obiektów zabytkowych nie przetrwało ze względu na kolejne przebudowy systemów fortyfikacyjnych oraz procesy defortyfikacji ${ }^{6}$, co niejednokrotnie było efektem procesów urba-
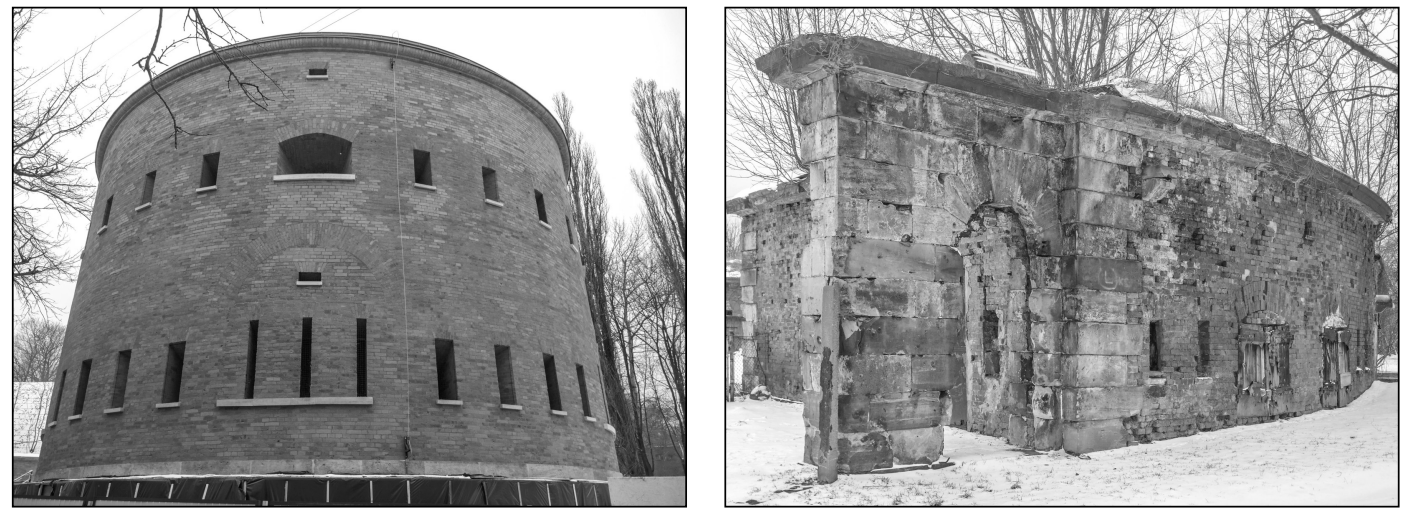

Ryc. 1. Przykład elementów fortyfikacji stałych: Twierdza Warszawa / Cytadela Warszawska (Aleksandrowska): kaponiera I bastionu - z lewej; pótkaponiery - z prawej (fot. R. Zapłata)

-konserwatorskich (ryc. 1, 2). Wiele obiektów zachowało się w gorszym stanie - całkowitej ruiny, co dotyczy również fortyfikacji trwałych. Zniszczony zasób dziedzictwa kulturowego wymaga szczególnych zabiegów celem wykrycia czy dokładniejszego przebadania. Dodatkowe komplikacje pojawiają się na terenach leśnych, gdzie widoczność jest ograniczona, a możliwości rozpoznawania zabytków, wizji terenowej czy prowadzenia np. prac geofizycznych utrudniają warunki wegetacyjne (ryc. 2c, 8, 9). Mimo że omawiane budowle przybierały często znaczące rozmiary czy też wyraźne formy i kształty, to w wyniku zniszczeń, procesów depozycyjnych i podepozycyjnych obecnie pozostają (w calości lub tylko elementy) poza zasięgiem tradycyjnego rozpoznania.

${ }^{5}$ I. Prądzyński, Umocnienia polowe, Warszawa 1986; K. Biesiekierski, K. Kleczke, M. Rewieński, Fortyfikacja polowa, Oświęcim 2014 (Warszawa 1929); Feld-pionierdienst aller Waffen, Berlin 1911. nistycznych oraz zmian, jakie wymuszała nowa taktyka wojenna. Również ten zasób dziedzictwa kulturowego wymaga dodatkowych dziatań celem zlokalizowania i zadokumentowania stanu obecnego, co w pewnym zakresie umożliwiają takie technologie jak ALS.

Innym zasobem obiektów zabytkowych są mniej trwałe elementy założeń militarnych - fortyfikacje polowe. Niszczejące już podczas użytkowania (ryc. 4), często słabo zachowane, nieczytelne w terenie (ryc. 8), jednak o istotnym znaczeniu dla całości założenia militarnego, niejednokrotnie

\footnotetext{
${ }^{6}$ I. Kozłowska, Szczecińskie fortyfikacje nowożytne. Rola fortyfikacji nowożytnych w ksztattowaniu układu przestrzennego miasta Szczecina oraz wpływ analizy historycznej na wspótczesne działania projektowe i zakres ochrony konserwatorskiej, Szczecin 2007, rozprawa doktorska (http://pbc.gda.pl/dlibra/doccontent?id =8063\&from $=F B C$, dostęp: 31 grudnia 2014); M. Omilanowska, Defortyfikacja Gdańska na tle przekształceń miast niemieckich w XIX w., „Biuletyn Historii Sztuki", 72, 2010, s. 293-334.
}

\section{2 Studia Geohistorica ・ Nr 03. 2015}


odgrywały znaczącą rolę w minionych wydarzeniach. Tego typu obiekty zazwyczaj nie mają jakiejkolwiek dokumentacji, a zasób archiwalny w nikłym stopniu umożliwia ich lokalizację i badanie. W pewnym zakresie wsparcie w rozpoznawaniu takich założeń militarnych oferują współ- czesna czy też historyczna fotografia lotnicza (ryc. 2b) oraz zobrazowania satelitarne. Niestety w większości przypadków nie można w ten sposób zweryfikować obiektów występujących na terenach zalesionych (ryc. 9), gdzie prospekcję zdecydowanie zmienia lotnicze skanowanie laserowe.

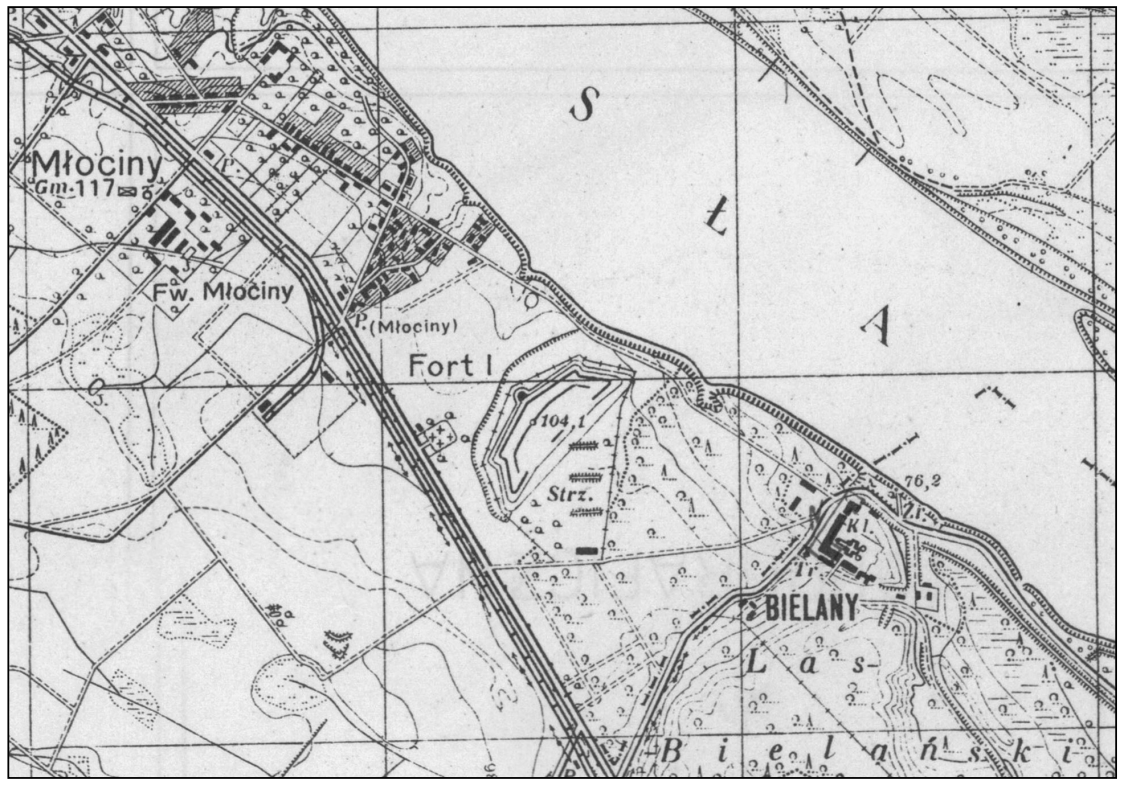

$a$

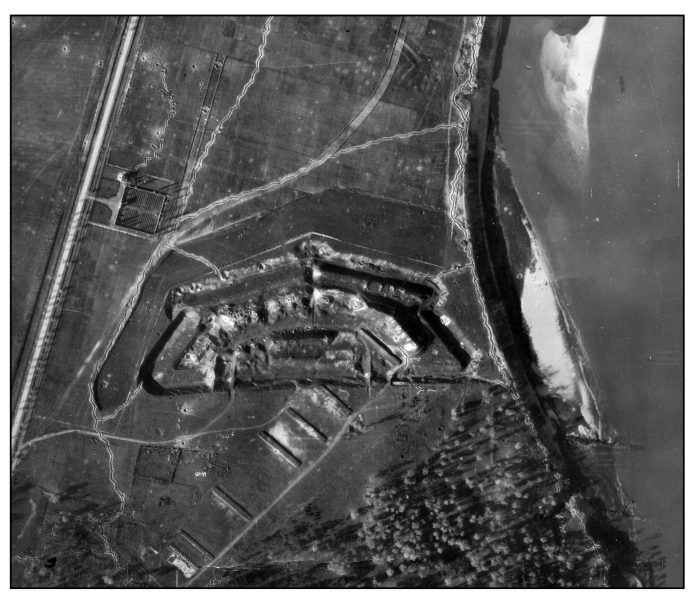

b

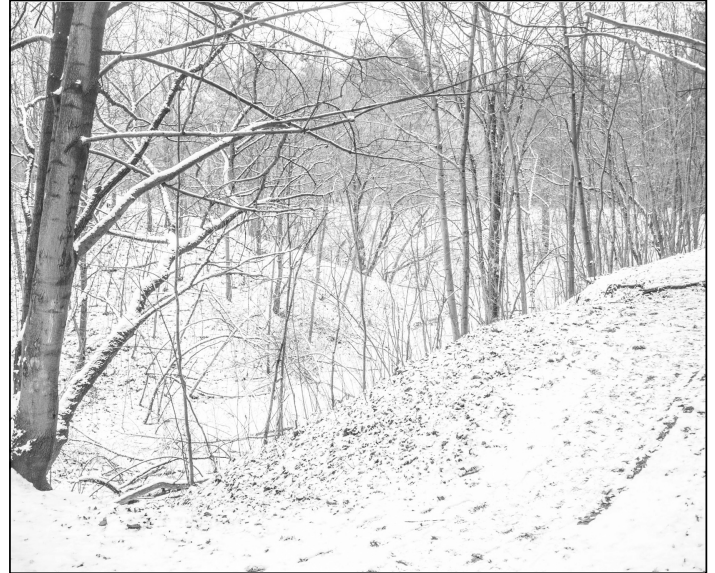

C

Ryc. 2. Twierdza Warszawa - Fort I (Bielany). Przykład znanej fortyfikacji z XIX w., położonej na zalesionych terenach miejskich, o stabej ekspozycyjności i czytelności niektórych elementów z uwagi na środowisko występowania: a) fragment przykładowej mapy archiwalnej Warszawa-Żoliborz 1:25 000 / 1934 / P39 S32 G (3932 G) Wojskowy Instytut Geograficzny (źródto: http://igrek.amzp.pl/); b) fragment przykładowego, lotniczego zdjęcia archiwalnego (źródło: NARA / zbiory S. Różycki); c) widok na elementy ziemne fortu (fot. R. Zapłata) 


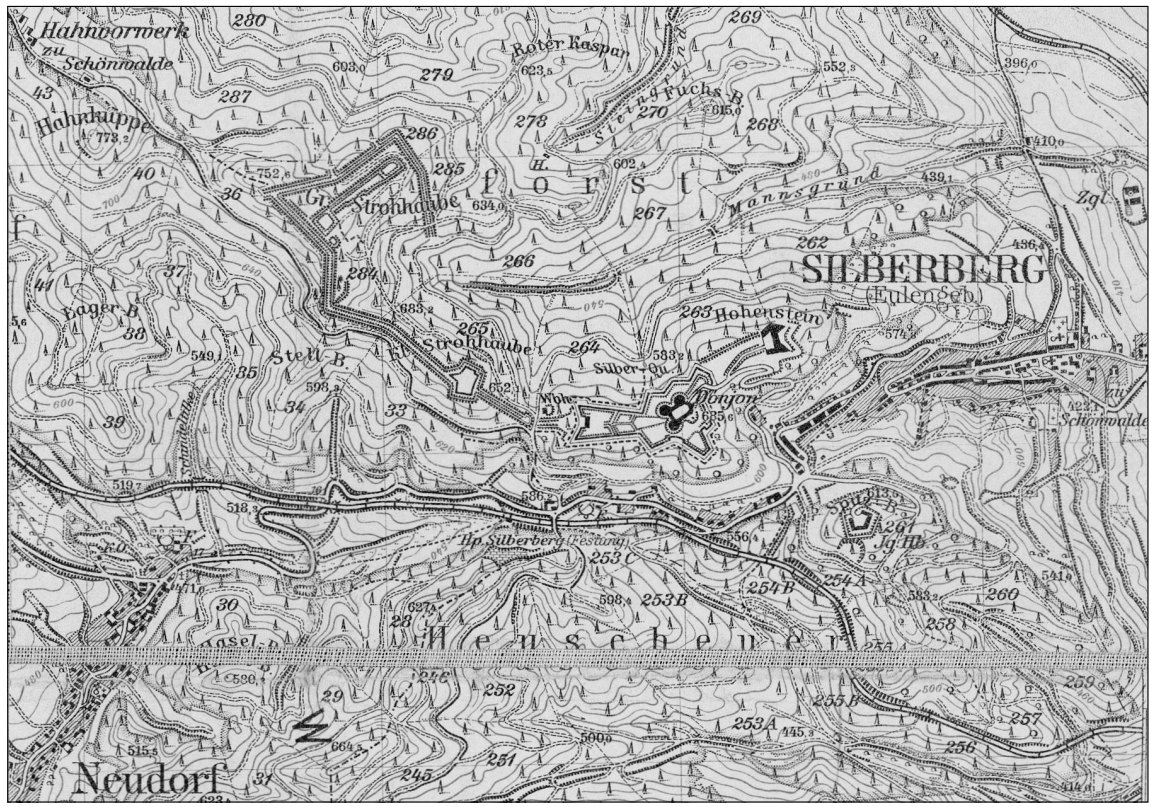

Ryc. 3. Fragment przykładowej mapy historycznej z lokalizacją i zasięgiem założeń obronnych Twierdzy Srebrna Góra. Przykład źródeł archiwalnych umożliwiających rozpoznawanie i analize obiektu. Zarówno fortyfikacje stałe, jak i polowe znajdują się obecnie na terenach leśnych. „Topographische Karte”, 1:25 000 (Meßtischblatt), Neurode, 5465 (3189), 1937. Żródto: Archiwum Map Zachodniej Polski (http://igrek.amzp.pl/; http://mapy.amzp.pl/)

a

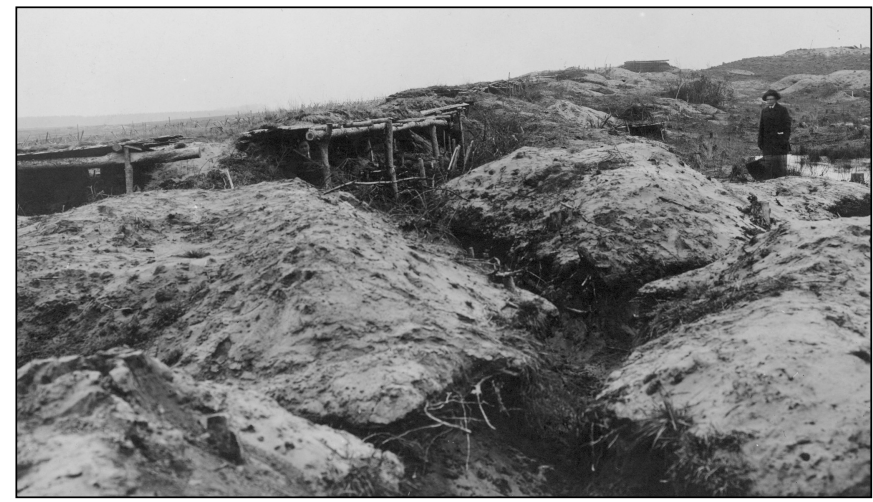

$b$

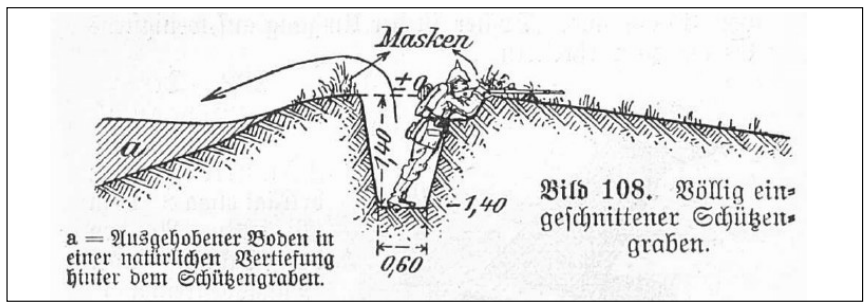

Ryc. 4. Przykład fortyfikacji polowych: a) zdjęcie archiwalne „Umocnienia wojskowe w okolicach Tarnobrzega - okopy z lat 1914-1915” (źródło: NAC); b) przekrój okopu ilustrujący szerokość i gtębokość tego typu fortyfikacji polowych (za: „Feldpionierdienst aller Waffen", Berlin 1911)

\section{IS4 Studia Geohistorica • Nr 03.2015}


Tak rysujący się obraz wielu obiektów fortyfikacyjnych, zwłaszcza polowych, doczekał się w ostatnich latach pionierskich prac nad rozpoznaniem i inwentaryzacją w oparciu o omawianą technologię ALS, która stwarza nowe możliwości badania i ochrony wielu obiektów zabytkowych wraz z narzędziami geoinformatycznymi.

\section{Lotnicze skanowanie laserowe a zabytkowe fortyfikacje - dane, przetworzenia i analiza wybranych przykładów}

Do zasadniczych zalet lotniczego skanowania laserowego zalicza się: nieinwazyjność, dokładność, szybkość i znaczną niezależność od warunków pogodowych, a także możliwość pomiaru - prospekcji powierzchni terenu (zwłaszcza rzeźby) w lasach ${ }^{7}$. M.in. w oparciu o dużą dokładność pomiarową, a następnie przez wygenerowanie numerycznych modeli terenu (NMT) możliwe jest rozpoznanie nawet szczątkowo zachowanych pozostałości obiektów, których różnice wysokościowe, a więc mikrorzeźba, sięgają nawet kilku centymetrów.

Dane ALS to zarazem rezultat pomiarów wykonywanych na potrzeby określonych projektów badawczych, ale i zasób, który powstaje w ramach przedsięwzięć niezwiązanych $\mathrm{z}$ dziedzictwem kulturowym, coraz częściej wykorzystywany w badaniach nieinwazyjnych. Przykładem jest projekt o nazwie „Informatyczny System Osłony Kraju przed nadzwyczajnymi zagrożeniami”. Jest to przedsięwzięcie realizowane $\mathrm{w}$ ramach 7. osi priorytetowej „Społeczeństwo informacyjne - budowa elektronicznej administracji" programu „Innowacyjna Gospodarka 2007-2013”. Projekt ten jest efektem działań Krajowego $\mathrm{Za}$ -

\footnotetext{
7 Szerzej na temat ALS zob. m.in.: R.H. Bewley, S. Crutchley, C. Shell, New light; K. Challis, P. Forlin, M. Kincey, A Generic Toolkit for the Visualization of Archaeological Features on Airborne LiDAR Elevation Data, „Archaeological Prospection”, 18 (4), 2011, s. 279-289; S. Crutchle, P. Crow, The Light Fantastic. Using Airborne Lidar in Archaeological Survey, "International Archives of the Photogrammetry, Remote Sensing and Spatial Information Sciences", 38, 2010, s. 160-164 (http:// www.isprs.org/proceedings/XXXVIII/part7/b/pdf/160 XXXVIIIpart7B. pdf, dostęp: 31 grudnia 2014); R. Hesse, Extraction of Archaeological Features from High-Resolution LIDAR Data, w: $14^{\text {th }}$ International Congress "Cultural Heritage and New Technologies" Vienna, 2009, [b.m.w.] 2010, s. 636-642 (http://www.academia.edu/1045403/
}

rządu Gospodarki Wodnej (lider konsorcjum), przy współpracy z Instytutem Meteorologii i Gospodarki Wodnej, Głównym Urzędem Geodezji i Kartografii, Rządowym Centrum Bezpieczeństwa i Instytutem Łączności (http:// www.gugik.gov.pl/projekty/isok). Głównym celem projektu jest utworzenie nowego elementu w znacznym stopniu poprawiającego osłonę społeczeństwa, gospodarki i środowiska przed skutkami powodzi (http://www.isok.gov.pl/pl/cele -podstawowe-projektu). Dostępność danych ISOK umożliwia ich wykorzystywanie również w celach naukowo-badawczych i konserwatorskich, w szczególności na terenach leśnych. W ramach omawianego projektu lotnicze skanowanie laserowe sięgnie większości powierzchni Polski. W oparciu o te pomiary generowane są produkty pochodne, np. numeryczne modele terenu. Skanowanie lotnicze obejmuje przede wszystkim obszary wyznaczone przez Krajowy Zarząd Gospodarki Wodnej, które potencjalnie zagrożone są powodzią ${ }^{8}$. Biorąc pod uwage obecny zasięg projektu i nadal trwające prace, należy stwierdzić, że teren pomiarów znacznie wykracza poza wstępnie przyjęte założenia (ryc. 6). Zasób danych tworzony jest w dwóch standardach na podstawie określonych parametrów technicznych, co przedstawia tabela 1.

Zasób danych ISOK dostępny jest zarówno dla osób prywatnych, jak i pomiotów realizujących zadania publiczne za pośrednictwem Głównego Urzędu Geodezji i Kartografii, a także Centralnego Ośrodka Dokumentacji Geodezyjnej i Kartograficznej (CODGiK), który gromadzi i udostępnia bazy danych centralnego zasobu geodezyjnego i kartograficznego w Polsce (http://www.codgik.gov.pl).

Extraction of archaeological features from high-resolution LIDAR data, dostęp: 31 grudnia 2014); Ł. Sławik, $\bar{R}$. Zapłata, LIDAR $w$ archeologii - zagadnienia wprowadzające, w: Digitalizacja dziedzictwa archeologicznego - wybrane zagadnienia, red. R. Zapłata, Lublin 2011, s. 207-232 (http://wiedzaiedukacja.eu/wp-content/uploads/2012/02/ Digitalizacja\%20dziedzictwa\%20archeologicznego $\% 20 \% 5 \mathrm{Bre}$ d\%5D\%20Rafal\%20Zaplata.pdf, dostęp: 31 grudnia 2014); T. Zawiła-Niedźwiecki i in., LIDAR w leśnictwie, „Teledetekcja Środowiska”, 39, 2008, s. 59-66.

8 Z. Kurczyński, K. Bakuła, The Selection of Aerial Laser Scanning Parameters for Countrywide Digital Elevation Model Creation, „SGEM2013 Conference Proceedings”, 2, 2013, s. 695-702. 
Tab. 1. Podstawowe parametry ALS w ramach ISOK

\begin{tabular}{|c|c|c|}
\hline Parametr & Standard I & Standard II \\
\hline $\begin{array}{c}\text { Gęstość chmury punktów (w pojedynczym } \\
\text { pasie obrazowania) }\end{array}$ & $\geq 4 \mathrm{pkt} / \mathrm{m}^{2}$ & $\begin{array}{l}\geq 12 \mathrm{pkt} / \mathrm{m}^{2} \text { (2 niezależne naloty, } \\
\left.\text { każdy o gęstości } \geq 6 \mathrm{pkt} / \mathrm{m}^{2}\right)\end{array}$ \\
\hline Równomierność gęstości punktów & $\begin{array}{l}\text { stosunek średniej odległości } \\
\text { punktów w linii do odległości linii } \\
\text { w przedziale } 1: 1,5 \div 1,5: 1\end{array}$ & $\begin{array}{l}\text { stosunek średniej odległości } \\
\text { punktów w linii do odległości linii } \\
\text { w przedziale } 1: 1,5 \div 1,5: 1\end{array}$ \\
\hline Kąt poprzeczny skanowania & $\begin{array}{l}\leq \pm 25^{\circ} \text { (dla obszarów niezale- } \\
\text { sionych dopuszcza się } \leq \pm 30^{\circ} \text { ) }\end{array}$ & $\leq \pm 25^{\circ}$ \\
\hline Pokrycie poprzeczne między szeregami & $\geq 20 \%$ & $\geq 20 \%$ \\
\hline Minimalna szerokość pasa pokrycia & $\geq 100 \mathrm{~m}$ & $\geq 100 \mathrm{~m}$ \\
\hline Maksymalna długość pojedynczego szeregu & $\leq 50 \mathrm{~km}$ & $\leq 50 \mathrm{~km}$ \\
\hline Szeregi poprzeczne w bloku ALS & min. 2 szeregi poprzeczne & $\begin{array}{l}2 \text { niezależne poprzeczne naloty, } \\
\text { zbędne dodatkowe szeregi po- } \\
\text { przeczne }\end{array}$ \\
\hline $\begin{array}{l}\text { Dokładność wysokościowa (błąd średni) } \\
\text { punktów ALS laserowych po wyrównaniu } \\
\text { (na płaskich utwardzonych nawierzchniach) }\end{array}$ & $\mathrm{mh} \leq 0,15 \mathrm{~m}$ & $\mathrm{mh} \leq 0,10 \mathrm{~m}$ \\
\hline Rejestracja wielokrotnych odbić (ech sygnału) & 4 odbicia & 4 odbicia \\
\hline $\begin{array}{l}\text { Rejestracja intensywności odbitych } \\
\text { sygnałów }\end{array}$ & tak & tak \\
\hline $\begin{array}{l}\text { Rejestracja skanowanego pasa terenu } \\
\text { średnioformatową kamerą cyfrową }\end{array}$ & $\begin{array}{l}\text { synchroniczna ze skanowaniem } \\
\text { (dopuszcza się rejestrację foto- } \\
\text { graficzną w innym terminie } \\
\text { niż skanowanie ALS) }\end{array}$ & synchroniczna ze skanowaniem \\
\hline Termin wykonania nalotów skanerowych & $\begin{array}{l}\text { od połowy października do końca } \\
\text { kwietnia }\end{array}$ & caty rok \\
\hline
\end{tabular}

Źródto: Z. Kurczyński, K. Bakuła, „The Selection”

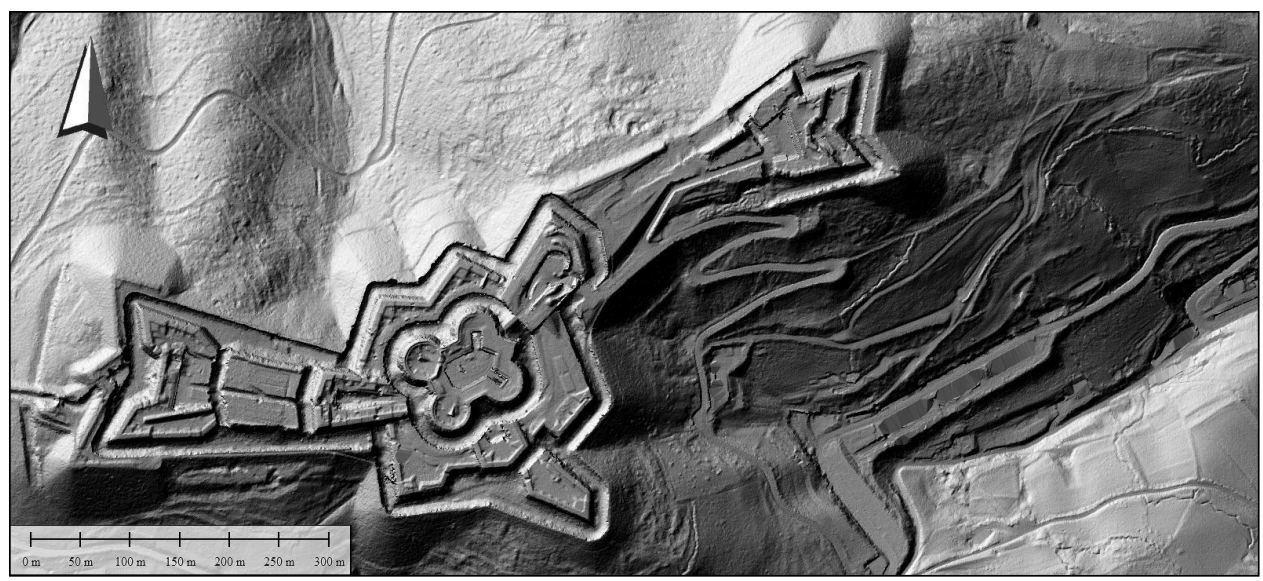

Ryc. 5. Wizualizacja rdzenia Twierdzy Srebrna Góra - mapa cieniowania rzeźby terenu i obiektu: trzon twierdzy z donżonem i wieńcem detaszowanych bastionów oraz Fort Rogowy l $i$ Fort Wysoka Skała.

Źródto: ISOK/MGGP Aero, za: R. Zapłata, „Twierdza Srebrna Góra w świetle przetworzeń i wizualizacji danych ALS I ISOK - przykład nieinwazyjnych badań zabytkowego założenia obronnego", Warszawa 2014, mps przechowywany w archiwum UKSW / MGGP Aero 
Dodatkową zaletą omawianego projektu jest dostęp do danych ALS online, zwłaszcza produktów pochodnych, takich jak numeryczne modele wysokościowe, modele cieniowe, o zróżnicowanej rozdzielczości, która w pewnym stopniu umożliwia analizę i rozpoznawanie obiektów zabytkowych. Usługę taką świadczą m.in. portale internetowe geoportal.gov.pl oraz e-zabytek.nid.pl, na których istnieje możliwość zintegrowanego $\mathrm{z}$ innymi warstwami tematycznymi (np. ortofotomapą, mapami topograficznymi) analizowania obszarów - również pod kątem detekcji i inwentaryzacji zabytków fortyfikacji nowożytnych. Jakość oraz potencjał tych zasobów ilustruje rycina 5, stanowiąca przykładową wizualizację danych ALS-ISOK dla Twierdzy Srebrna Góra - model cieniowy.

\section{ALS - pomiar i jakość danych}

Lotnicze skanowanie laserowe od wielu lat $\mathrm{z}$ dużym powodzeniem sprawdza się w odniesieniu do badania zabytków archeologicznych' ${ }^{9}$, historycznych zamków ${ }^{10}$, ale i fortyfikacji nowożytnych w Polsce i na świecie ${ }^{11}$. Przede wszystkim

\footnotetext{
9 Wybrane przykłady polskich badań w zakresie ALS: J. Nowakowski, Airborne Laser Scanning (ALS) w polskiej archeologii. Próby, doświadczenia, wyniki, Poznań 2010, referat wygtoszony na „XIX Konferencji Sprawozdawczej. Badania archeologiczne na Nizinie Wielkopolsko-Kujawskiej w latach 2008-2009"; Ł. Sławik, R. Zapłata, LIDAR w badaniach archeologicznych, Warszawa 2010, prezentacja na konferencji „Metody geofizyczne w archeologii polskiej"; R. Zapłata, LIDAR w archeologii. Pilotażowy projekt zastosowania lotniczego skaningu laserowego $w$ archeologii - wybrane tereny na obszarze woj. wielkopolskiego i tódzkiego, Warszawa 2010, mps przechowywany w archiwum UKSW; tenże, Nieinwazyjne metody w badaniu i dokumentacji dziedzictwa kulturowego - aspekty skanowania laserowego w badaniach archeologicznych $i$ architektonicznych, Warszawa 2013; Ł. Banaszek, W. Rączkowski, Potencjat danych ALS w badaniach archeologicznych, w: Podręcznik dla uczestników szkoleń z wykorzystania produktów LiDAR, Kraków 2014, s. 192-200 (http://szkolenialidar.gugik.gov.pl/szkolenia /materialy-szkoleniowe/podrecznik/, dostęp: 31 grudnia 2014), K. Bakuła, W. Ostrowski, R. Zapłata, Automatyzacja w procesie detekcji obiektów archeologicznych z danych ALS, „Folia Praehistorica Posnaniensia", 19, 2014, s. 189-206.

${ }^{10} \mathrm{~A}$. Borkowski, G. Jóźków, Ocena dokładności modelu 3D zbudowanego na podstawie danych skaningu laserowego - przykład zamku Piastów Śląskich w Brzegu, „Archiwum Fotogrametrii, Kartografii i Teledetekcii", 23, 2012, s. 37-47; M. Legut-Pintal, LiDAR w badaniach nad średniowiecznymi fortyfikacjami i siedzibami obronnymi Przykład założeń obronnych księstwa biskupów wrocławskich (http:// www.academia.edu/3102476/LiDAR w badaniach nad srednio wiecznymi fortyfikacjami i siedzibami obronnymi. Przyklad zalozen obronnych ksiestwa biskupow wroclawskich, dostęp: 31 grud-
}

rozpoznawanie nowych obiektów, weryfikacja znanych czy w końcu inwentaryzacja zabytkowych założeń - to cechy definiujące potencjał omawianej metody. Obok zalet obserwujemy pewne ograniczenia, co skłania do podjęcia działań na rzecz ich wyeliminowania i poprawy jakości prac inwentaryzacyjno-badawczych. Cechą charakterystyczną wykonywanych pomiarów, a zarazem pozyskiwanych danych (m.in. z projektu ISOK) jest ich zróżnicowana jakość. Już sam pomiar i parametry techniczne wnoszą na początkowych etapach prac zróżnicowaną jakość danych przestrzennych, rzutując bezpośrednio na analizę zasobów zabytkowych, czego przyczyny należy upatrywać m.in. w: rodzajach skanerów - typach sensorów, długościach fal, pokryciu poprzecznym pomiędzy pasami, kącie skanowania $^{12}$.

Analizując dane pozyskiwane i przetwarzane na potrzeby konkretnych projektów badawczych (jak również wykorzystywane dane ISOK) w zakresie poszukiwania i inwentaryzacji dziedzictwa kulturowego, dostrzegamy kilka zasadniczych cech, a zarazem ograniczeń ${ }^{13}$.

nia 2014); W. Ostrowski, K. Bakuła, R. Zapłata, A New Look at Historic Fortifications - Medieval Castles and Airborne Laser Scanning, w: Anthropology, Archaeology, History, Philosophy. Conference proceedings - SGEM, International Multidisciplinary Scientific GeoConference SGEM - Bulgaria, Albena, Albena 2014, s. 307-314.

11 M. Antoszewski, W. Ostrowski, Lotniczy skaning; K. Pavelka i in., Some Using of Airborne Laser Scanning in Archaeology, w: Towards Horizon 2020: Earth Observation and Social Perspectives, EARSeL, Symposium Proceedings, ed. R. Lasaponara, N. Masini, M. Biscione, Matera 2013, s. 849-856 (http://www.earsel.org/symposia/2013-symposiumMatera/pdf proceedings/EARSeL-Symposium-2013 141 pavelka. pdf, dostęp: 31 grudnia 2014); W. Ostrowski, D. Zawieska, Airborne Laser Scanning; D. Zawieska, W. Ostrowski, M. Antoszewski, Wykorzystanie danych.

$12 \mathrm{~K}$. Stereńczak, Lotnicze skanowanie laserowe, w: Las w rastrowym modelu danych przestrzennych, red. K. Będkowski, Warszawa 2011, s. 63-74; R. Zapłata, Nieinwazyjne metody; K. Stereńczak, Skanowanie laserowe i geomatyka, w: Laserowi odkrywcy. Nieinwazyjne badanie i dokumentowanie obiektów archeologicznych i historycznych województwa świętokrzyskiego, red. R. Zapłata, B. Szady, K. Stereńczak, Stare Babice 2014, s. 92-110.

13 M. Doneus, C. Briese, Full-Waveform Airborne Laser Scanning as a Tool for Archaeological Reconnaissance, w: From Space to Place. Proceedings of the $2^{\text {nd }}$ International Workshop on Remote Sensing in Archaeology, CNR, Rome, Italy, 4-7 December, ed. S. Campana, M. Forte, Oxford 2006, s. 99-105 (http://publik.tuwien.ac.at/files/ PubDat 120639.pdf, dostęp: 31 grudnia 2014); R. Zapłata, Nieinwazyjne metody; K. Stereńczak, Skanowanie laserowe; Ł. Banaszek, W. Rączkowski, Potencjat danych. 


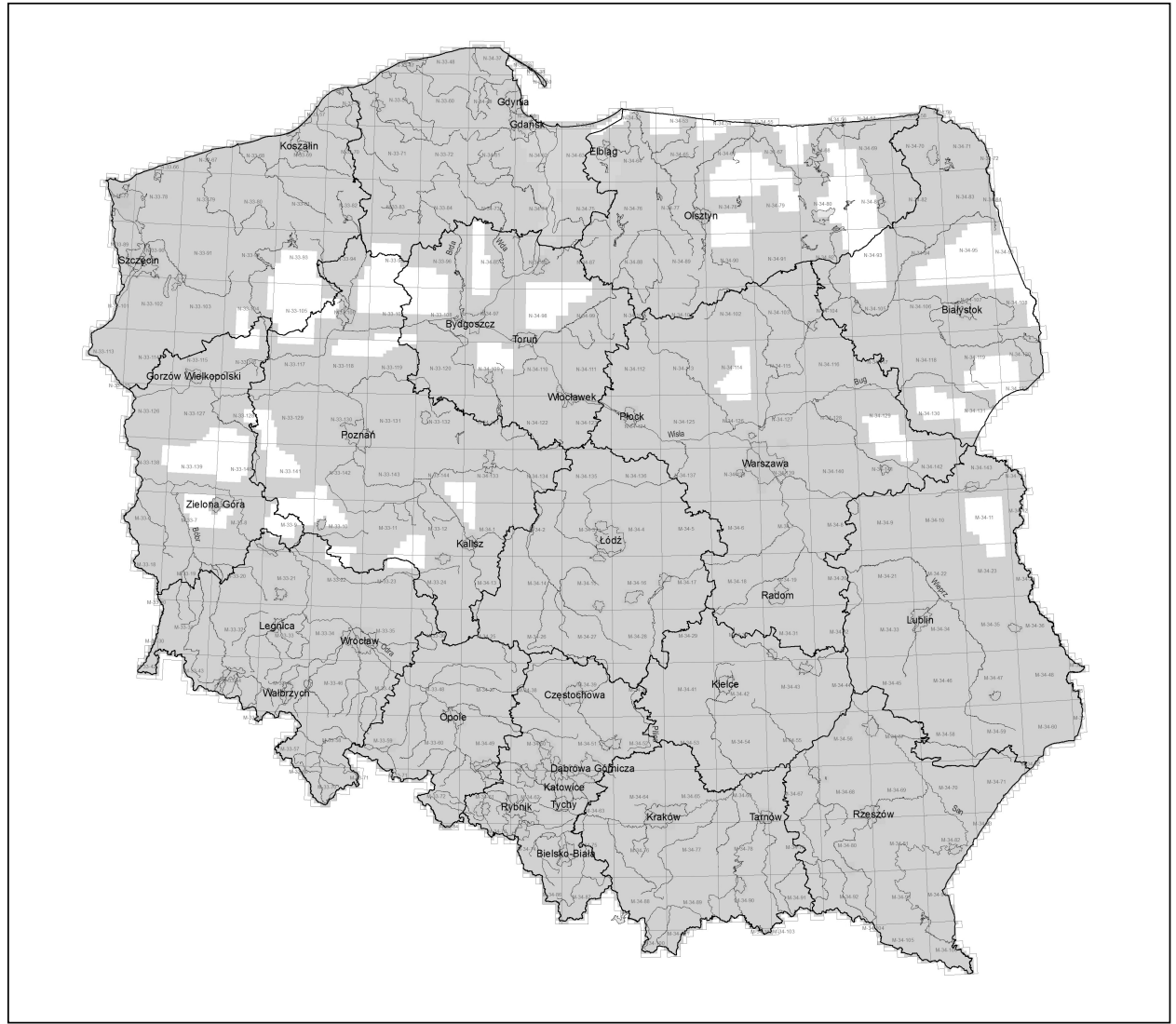

Ryc. 6. Planowany obszar, na którym zostanie wykonane lotnicze skanowanie laserowe w ramach projektu ISOK. Źródto: http://geoforum.pl/?page =news\&id=17477\&link=kolejne-umowy-na-lotniczy-skaning-podpisane\& menu $=46879,46880$, dostęp: 31 grudnia 2014

Po pierwsze, jak już wspomniano, dane te są niejednorodne jakościowo, co należy wiązać $\mathrm{z}$ jednej strony $\mathrm{z}$ parametrami i warunkami technicznymi wykonywanych pomiarów (w tym wskazaniami odbiorców pomiarów), a $\mathrm{z}$ drugiej $\mathrm{z}$ warunkami, jakie $\mathrm{w}$ momencie nalotu charakteryzują skanowany obszar, np. teren otwarty lub zalesiony (ryc. 7). Również sezonowe występowanie określonych gatunków roślin (zwłaszcza w okresach sprzyjających pomiarowi, np. wiosną), a także panujące warunki wilgotnościowe mogą wprowadzać istotne zakłócenia $\mathrm{w}$ pozyskiwaniu danych przestrzennych. Po drugie, przetwarzanie danych odbywa się w różnorodny sposób, zwłaszcza na etapie klasyfikacji chmury punktów i generowania np. numerycznych modeli terenu, które niejednokrotnie stanowią podstawowy zestaw danych służący wyszukiwaniu i wskazywaniu potencjalnych obiektów zabytkowych. Pozyskany i przetworzony zasób danych o wyżej zarysowanych cechach wymaga np. dalszych prac weryfikacyjnych (terenowych), które mogaz w pewnym zakresie skorygować ich jakość (dokładność).

Kolejne zagadnienie to przetwarzanie pozyskanych i wygenerowanych danych, zawierających informację przestrzenną o powierzchni terenu i obiektów, a także pokryciu terenu. W procesie badawczym znaczące dla analiz jest m.in. generowanie NMT o różnorodnej rozdzielczości przestrzennej, np. pikseli $1 \mathrm{~m}, 0,5 \mathrm{~m}$ czy $0,2 \mathrm{~m}$, które wprowadzają odmienną jakość analizowania powierzchni terenu oraz szcząt- 


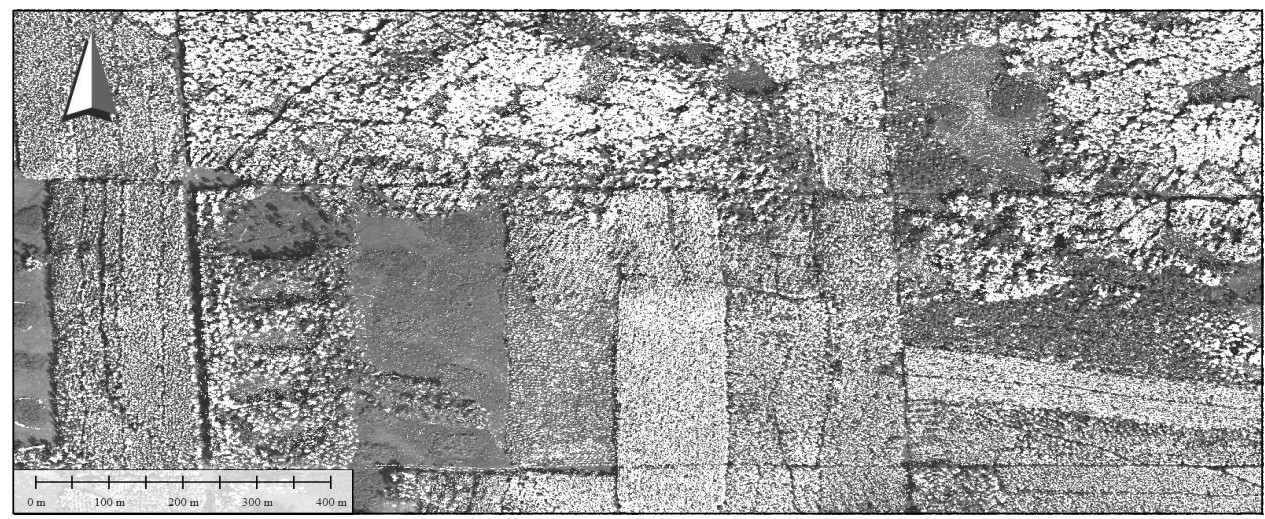

Ryc. 7. Przykładowa wizualizacja rozkładu chmury punktów (pomiarów ALS) na powierzchni terenu: odcień jaśniejszy (biały) - powierzchnie o niskiej gęstości i zróżnicowanym rozkładzie punktów na powierzchni terenu (obszar zalesiony); odcień ciemniejszy - powierzchnie o dużej gęstości i dość jednolitym rozkładzie punktów na powierzchni terenu (np. tereny odsłonięte). Źródło: ISOK / UKSW. Oprac. R. Zapłata

kowo zachowanych zasobów zabytkowych ${ }^{14}$. Sytuację może zilustrować analiza tego samego obszaru na bazie omawianych wcześniej zasobów online ${ }^{15}$ przy różnorodnej rozdzielczości NMT - im mniejsza rozdzielczość, tym gorsza jakość odzwierciedlenia powierzchni terenu, a zwłaszcza zabytków.

\section{Metody przetwarzania i wizualizacji danych ALS}

Rezultaty pomiarów ALS na etapie prac kameralnych poddawane są wielu procesom obróbki, a następnie przetworzeniom i wizualizacji celem przeanalizowania powierzchni terenu i rozpoznania różnic wysokościowych, które mogą stanowić pozostałości potencjalnych lub znanych obiektów zabytkowych. Obok powszechnie stosowanego przetwarzania i wizualizacji danych ALS, np. w postaci modelu cieniowego (ang. hill-shaded relief), w ostatnich latach coraz powszechniej rozwijane są inne techniki, umożliwiające dokładniejszą analizę zeskano-

\footnotetext{
${ }^{14}$ Szerzej zob.: K. Bakuła, W. Ostrowski, R. Zapłata, Automatyzacja w procesie; R. Zapłata, K. Bakuła, W. Ostrowski, Transformation Methods and ALS-data Visualization in the Studies of Historical Charcoal Piles, w: Anthropology, Archaeology, History, Philosophy. Conference Proceedings - SGEM, International Multidisciplinary Scientific GeoConference SGEM - Bulgaria, Albena, Albena 2014, s. 417-424.

15 http://mapy.geoportal.gov.pl/imap/?gpmap=gp0, dostęp: 31 grudnia 2014.
}

wanej powierzchni terenu, $\mathrm{w}$ tym pozostałości zabytkowych fortyfikacji. Na szczególną uwagę zastugują omawiane $\mathrm{w}$ literaturze przedmiotu przetworzenia typu: hill-shading from multiple directions, openness, local relief model czy sky-view factor, które umożliwiają rozpoznawanie m.in. fortyfikacji polowych, zwłaszcza o nikłym zarysie i słabej ekspozycji terenowej. Do badań nad dziedzictwem kulturowym (również w Polsce) od kilku lat coraz częściej stosowane są zróżnicowane przetworzenia, których użycie zwiększa potencjał danych ALS, a także skuteczność rozpoznawania obiektów zabytkowych. Dostrzegamy m.in. uwzględnienie różnego rodzaju przetworzeń w detekcji, analizie i inwentaryzacji zabytków archeologicznych ${ }^{16}$, zabytkowej architektury ${ }^{17}$, dziedzictwa przemysłowo-gospodarczego $^{18}$, jak również XX-wiecznych fortyfikacji polowych $^{19}$. Doświadczenia własne autora, jak również literatura przedmiotu wskazują, że uzasadnione czy wręcz wskazane jest uwzględnienie

${ }^{16}$ K. Bakuła, W. Ostrowski, R. Zapłata, Automatyzacja w procesie; R. Zapłata, K. Bakuła, W. Ostrowski, Transformation Methods.

17 W. Ostrowski, K. Bakuła, R. Zapłata, A New Look.

18 R. Zapłata, M. Borowski, GIS w archeologii - przykład prospekcji i inwentaryzacji dziedzictwa archeologiczno-przemystowego, ,,Roczniki Geomatyki", 11 (4/61), 2013, s. 103-112; Laserowi odkrywcy; R. Zapłata, K. Bakuła, W. Ostrowski, Transformation Methods.

19 R. Zapłata, Okopy wojskowe z I wojny światowej w świetle lotniczego skanowania laserowego - Pakosław, woj. mazowieckie, Warszawa 2014, poster przechowywany w archiwum UKSW; Laserowi odkrywcy. 
różnego rodzaju przetworzeń w badaniach fortyfikacji nowożytnych. Podobieństwo form terenowych obiektów militarnych do archeologicznych czy ruin zamków to zasadnicze argumenty na rzecz dokładniejszego rozpoznawania elementów wielu nowożytnych założeń obronnych $\mathrm{z}$ zastosowaniem omawianych narzędzi geoinformatycznych. Jakie zatem rodzaje przetworzeń możemy zastosować w detekcji, inwentaryzacji i analizie zabytkowych fortyfikacji?

Powszechnie stosowanym przetworzeniem, a zarazem sposobem wizualizowania danych ALS, w tym historycznych obiektów militarnych, jest tzw. cieniowanie zboczy (ang. hill-shading - HS), czyli najogólniej mówiąc, przetworzenie polegające na symulacji oświetlania, w wyniku którego powstaje model cieniowy powierzchni terenu lub obiektu, podkreślający występujące nierówności powierzchni danego obszaru. Ta dość intuicyjna wizualizacja nie jest jednak najlepszym rozwiązaniem w rozpoznawaniu obiektów zabytkowych, gdyż w wyniku tego przetworzenia nie wszystkie deniwelacje terenu są tak czytelne, jak w wypadku innych, na co wskazuje literatura przedmiotu i prezentowane niżej przetworzenia dla fortyfikacji polowych (ryc. 10a) oraz elementów stałych architectura militaris (ryc. 12a) ${ }^{20}$. Pewnym rozszerzeniem tego przetworzenia jest wielokierunkowe cieniowanie zboczy (ang. hill-shading from multiple directions - HSMD), umożliwiające wizualizacje modelu terenu oświetlanego z kilku kierunków i z różnej wysokości jednocześnie. Daje ono obszerniejszą i pełniejszą analizę nierówności terenu, podkreślając zarys zabytkowych fortyfikacji (ryc. 10b, 12b) ${ }^{21}$.

Kolejnym rodzajem wizualizacji danych jest rezultat przetwarzania pozwalającego analizować nachylenie terenu (ang. slope) oraz jego ekspozycje

20 R. Bennett i in., A Comparison of Visualization Techniques for Models Created from Airborne Laser Scanned Data, „Archaeological Prospection", 19, 2012, s. 41-48.

21 D. Loisios, N. Tzelepis, B. Nakos, A Methodology for Creating AnaIytical Hill-Shading by Combining Different Lighting Directions, W: Proceedings of the $23^{\text {rd }}$ International Cartographic Conference, Moscow, August 2007, Moscow 2007 (http://www.mountaincar tography.org/publications/papers/ica_cmc_sessions/5_Moscow Session_Mountain_Carto/moscow_loisios.pdf, dostęp: 31 grudnia 2014). (ang. aspect). Rezultatem tego typu przetworzeń są mapy przedstawiające np. stopień nachylenia zbocza wałów fortyfikacyjnych (ryc. 12d) czy też ich ekspozycję zachodnią, południową itd.

Inną formą przetwarzania danych jest tzw. openness - otwarcie (współczynnik otwarcia topograficznego), w którym wizualizacji poddawany jest współczynnik topograficzny, definiowany jako „maksymalny lub minimalny kąt widoczności ograniczanej topografią na zadanym obszarze"22. Ten sposób przetwarzania danych przestrzennych charakteryzuje jednak pewien mankament, mianowicie bez względu na wartość nachylenia duże, regularnie nachylone powierzchnie prezentują się jak płaskie ${ }^{23}$. W związku z powyższym na przetworzeniach tych utrudniona jest analiza większych form terenowych, np. deniwelacji otoczenia obiektów (wzniesienia itp.), co widać w odniesieniu do wschodniego naroża Fortu Chochoł Mały (ryc. 12c). Mimo tego opennes stanowi kolejny sposób analizowania i wskazywania reliktów fortyfikacji, zwłaszcza form mikro, umożliwiając np. wizualizację zarysu fortyfikacji stałych o znacznym spadku (nachyleniu), co jest widoczne dla Fortu Chochoł Mały, zwłaszcza dla fleszy i jej północnego zarysu, słabo widocznego na przetworzeniach typu bill-shaded (ryc. 12a, 12b).

Kolejne przetworzenie - traktowane $\mathrm{w}$ literaturze przedmiotu jako jedno z lepszych do detekcji obiektów archeologicznych i wnoszące odmienną perspektywę analizowania nierówności terenu, a tym samym pozostałości po historycznych fortyfikacjach - to przetworzenie danych na bazie lokalnego modelu rzeźby terenu (ang. local relief model - LRM) ${ }^{24}$. LRM charakteryzuje się wyodrębnianiem obiektów

22 P.L. Guth, Terrain Organization Calculated From Digital Elevation Models, w: Concepts and Modelling in Geomorphology: International Perspectives, ed. I.S. Evans i in., Tokyo 2003, s. 199-220, za: M. Kasprzak, A. Traczyk, Geomorfometria granitowej części Karkonoszy, ,Landform Analysis”, 13, 2010, s. 33-46.

23 M. Doneus, Openness as Visualization Technique for Interpretative Mapping of Airborne Lidar Derived Digital Terrain Models, „Remote Sensing", 5 (12), 2013, s. 6427-6442; W. Ostrowski, K. Bakuła, R. Zapłata, A new look.

24 R. Hesse, Lidar-Derived Local Relief Models - a New Tool for Archaeological Prospection, „Archaeological Prospection”, 17, 2010, s. 67-72. 
o małych różnicach wysokościowych przy jednoczesnym wyłączaniu $\mathrm{z}$ analizy większych form terenowych. Najogólniej mówiąc, polega ono na usunięciu z podstawowego NMT form wysokich przy jednoczesnym pozostawieniu form niskich ${ }^{25}$. W efekcie zastosowania tego przetworzenia mamy możliwość np. rozpoznawania obiektów mikro dla terenów płaskich, co sprzyja detekcji np. słabo zachowanych fortyfikacji polowych na terenach o małym zróżnicowaniu wysokościowym (ryc. 12d).

Dość często stosowanym w badaniach obiektów zabytkowych przetworzeniem jest współczynnik widoku nieba (ang. sky-view factor - SVF), który najogólniej mówiąc, doprowadza do określenia wartości dla poszczególnych jednostek (pikseli) NMT, zróżnicowanej w zależności od ilości promieni docierających z hemisfery $^{26}$. Zaletą tego przetworzenia jest m.in. dość jednolita wizualizacja wklęsłych elementów obiektów, np. dna okopów czy stanowisk strzelniczych (ryc. 12e), a także wizualizacja wyraźnych zarysów elementów fortyfikacji stałych (ryc. 12f), porównywalna $\mathrm{z}$ przetworzeniem typu openness.

Dla potrzeb niniejszego artykułu przeanalizowano również przetworzenia typu analiza składowych głównych (ang. principal component analysis - PCA) czy indeks pozycji topograficznej (ang. topographic position index - TPI), które potwierdziły swą użyteczność $\mathrm{w}$ analizowaniu fortyfikacji na terenach zalesionych. Analiza składowych głównych to metoda, która „umożliwia kompresję najbardziej przydatnej, w późniejszym procesie klasyfikacji, informacji zawartych w obrazie przez utworzenie zmiennych nazywanych składowymi głównymi (ang. principal components). Wyznaczenie w procesie PCA głównych składowych polega na wyznaczeniu nowej osi głównej układu współrzędnych spektralnych wzdłuż najwięk-

25 B. Štular i in., Visualization of Lidar-Derived Relief Models for Detection of Archaeological Features, „Journal of Archaeological Science", 39, 2012, s. 3354-3360; R. Zapłata, M. Borowski, GIS $w$ archeologii; R. Zapłata, K. Bakuła, W. Ostrowski, Transformation Methods.

26 K. Zakšek, K. Oštir, Ž. Kokalj, Sky-View Factors as a Relief Visualization Technique, „Remote Sensing”, 3, 2011, s. 398-415 szej wariancji danych przez rzutowanie wartości pikseli obrazu w przestrzeni wielowymiarowej. Następnie wyznaczane są prostopadłe osie do pierwszej, także według maksymalnej wariancji (najistotniejszej statystycznie informacji). W ten sposób powstają nowe kanały zawierające wzajemnie nieskorelowane dane"27. PCA, podobnie jak wcześniej przywołane metody, umożliwia rozpoznawanie obiektów z pewnymi ograniczeniami. Po pierwsze, charakteryzuje ją przesunięcie obiektów, co wyklucza dokładną inwentaryzację na podstawie generowanych wizualizacji, a po drugie, kompozycje barwne mają nieintuicyjny wygląd ${ }^{28}$. W porównaniu $\mathrm{z}$ innymi omawianymi przetworzeniami PCA należy zaliczać do metod o niższym potencjale wykrywania pozostałości obiektów zabytkowych.

Indeks pozycji topograficznej ${ }^{29}$, najogólniej rzecz ujmując, to „procedura obliczania topograficznego wskaźnika pozycji [która] polega na porównaniu dwóch modeli rastrowych: oryginalnego DEM i modelu uśrednionych wysokości [...]. Wartości w tym drugim modelu wyliczane są jako średnia wartość wysokości w konkretnym otoczeniu - sąsiedztwie o z góry zadanym promieniu (np. 500 m, $2000 \mathrm{~m}$ itp.). Tak wykonana nowa warstwa - model rastrowy - informuje o tym, o ile w danym punkcie wysokość powierzchni obrazującej realny relief terenu odbiega od powierzchni uśrednionej. Innymi słowy, jest to wskaźnik określający względne położenie morfologiczne. Wartości dodatnie wskazują, że mamy do czynienia z elementem elewowanym (kulminacja, grzbiet), wartości ujemne - wskaźniki TPI oznaczają natomiast miejsca depresji (obniżenia dolinne, zagłębienia). Wartości pośrednie (oscylujące wokół zera) TPI odpowiadają powierzchniom stokowym,

27 B. Zagajewski, A. Jarocińska, D. Olesiuk, Metody i techniki badań geoinformatycznych, Warszawa 2009, s. 71.

28 B. Štular i in., Visualization; R. Bennett i in., A Comparison; Ž. Kokalj, K. Zakšek, K. Oštir, Visualizations of Lidar Derived Relief Models, w: Interpreting Archaeological Topography - Airborne Laser Scanning, Aerial Photographs and Ground Observation, ed. R.S. Opitz, D.C. Cowley, Oxford 2013, s. 100-114.

${ }^{29}$ A.D. Weiss, Topographic Position and Landforms Analysis, [b.m.w.] 2001 (http://www.jennessent.com/downloads/tpi-poster-tnc $18 \times 22$. pdf, dostęp: 31 grudnia 2014); Ž. Kokalj, K. Zakšsk, K. Oštir, Visualizations; M. Doneus, C. Briese, Full-Waveform. 


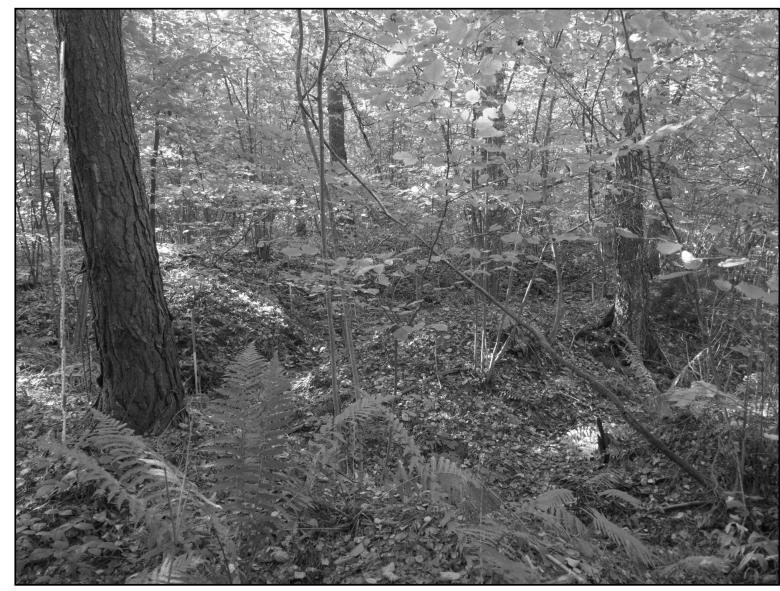

Ryc. 8. Pakostaw, woj. mazowieckie - przykład fortyfikacji polowych na terenach zalesionych. Konstrukcje zniszczone, stabo czytelne w terenie, o znikomej dokumentacji archiwalnej (fot. R. Zapłata)

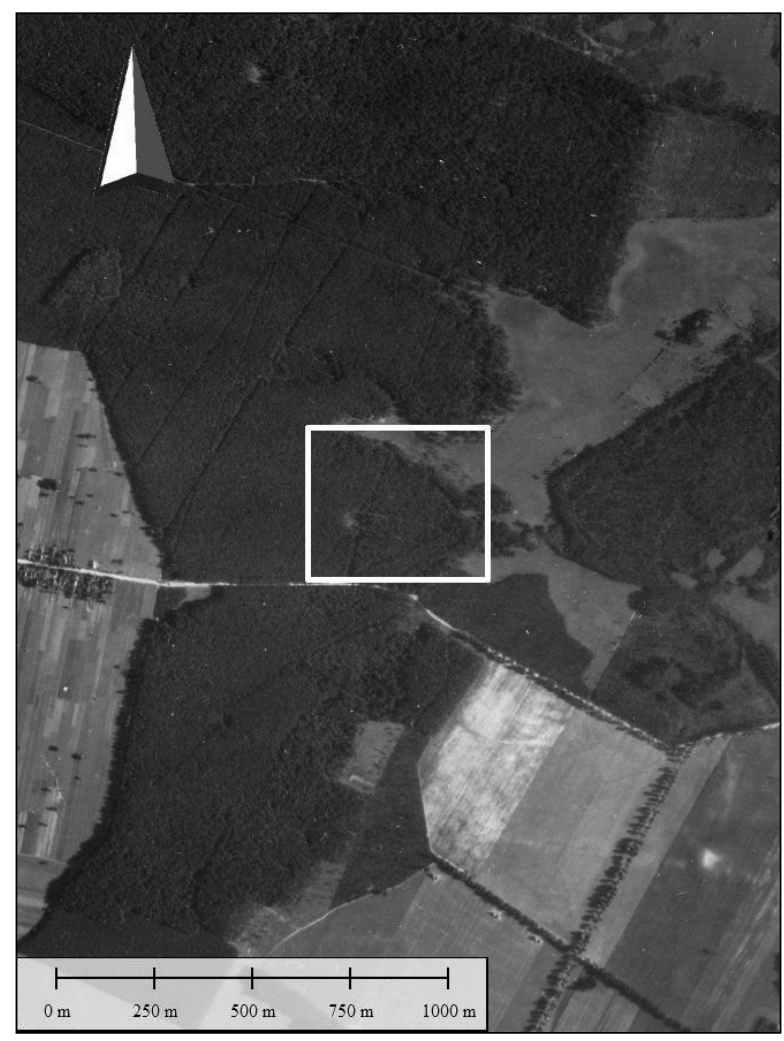

Ryc. 9. Pakostaw, woj. mazowieckie - brak widoczności z lotu ptaka fortyfikacji na terenach zalesionych. Zdjęcia archiwalne z 1943 r. (widoczność fortyfikacji dla tego samego terenu na bazie danych ALS zob. ryc. 10). Źródto: NARA/UKSW a zbliżone do zera - spłaszczeniom"30. Omawiane przetworzenie porównywalne jest do LRM i umożliwia przede wszystkim rozpoznawanie małych form terenowych.

Przedstawione przykładowe wyniki przeprowadzonych analiz oraz omówione narzędzia geoinformatyczne są przede wszystkim potwierdzeniem skuteczności i potencjału prezentowanych metod (lotnicze skanowanie laserowe wraz z omawianymi przetworzeniami danych przestrzennych) w zakresie detekcji oraz inwentaryzacji zabytkowych fortyfikacji, zwłaszcza na terenach leśnych. Metody umożliwiają wizualizację silnie zniszczonych (zniwelowanych) zabytków, czego przykładem są pozostałości analizowanych fortyfikacji polowych - okopów, które charakteryzują miejscami różnice wysokościowe rzędu kilkunastu centymetrów. Podsumowując tę część rozważań, warto powtórzyć raz jeszcze, że w odniesieniu do reliktów fortyfikacji stałych przetwarzane dane ALS pozwalają na: nieinwazyjną inwentaryzację obiektów, monitorowanie zachodzących zmian, w tym np. analizę i diagnozę procesów osuwiskowych, jak również rozpoznawanie elementów zachowanych $\mathrm{w}$ formie zniwelowanych wyniesień lub zagłębień, stanowiących pozostałości historycznych obiektów. Oceniając zakres i jakość poszczególnych przetworzeń, należy podkreślić konieczność wykonywania różnego rodzaju analiz i łączenia wizualizacji z uwagi na zróżnicowanie otoczenia obiektów, jak i stan ich zachowania. Przeprowadzone prace oraz przywoływana literatura przedmiotu wskazują, że ALS wraz $z$ omówionymi przetworzeniami oraz weryfikacyjnymi pracami terenowymi (np. badania powierzchniowe, wizja lokalna) stanowią obecnie najlepsze rozwiązanie w nieinwazyjnym badaniu zabytkowych fortyfikacji na terenach leśnych, umożliwiając zarówno analizę znanych zabytków, jak i wskazywanie potencjalnych obiektów do dalszego badania.

\footnotetext{
30 M. Kasprzak, A. Traczyk, Geomorfometria; A.D. Weiss, Topographic Position; J. Jennees, Topographic Position Index (TPI) v. 1.2, [b.m.w.] 2006 (http://www.jennessent.com/downloads/TPI_Documentation_ online.pdf, dostęp: 31 grudnia 2014).
} 


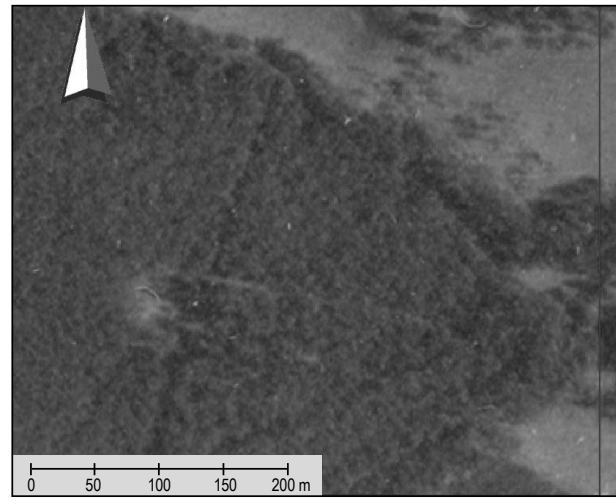

Fragment zdjęcia archiwalnego

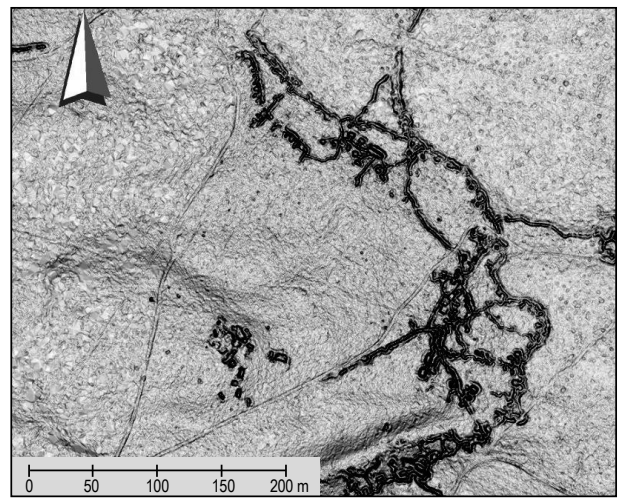

b) wielokierunkowe cieniowanie zboczy

(ang. multidirectional hill-shading)

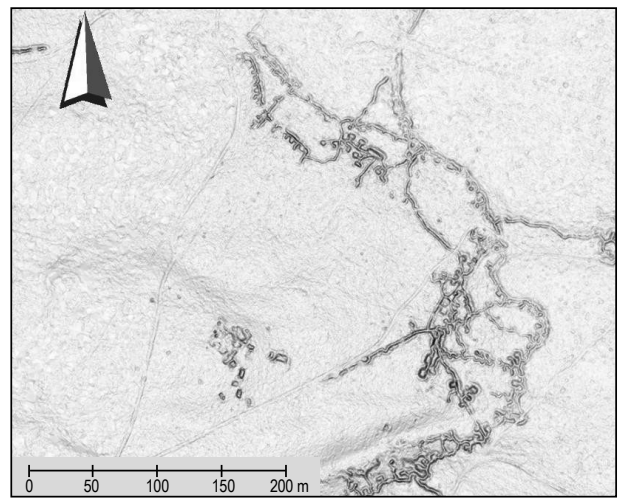

d) Iokalny model rzeźby terenu (ang. local relief model)

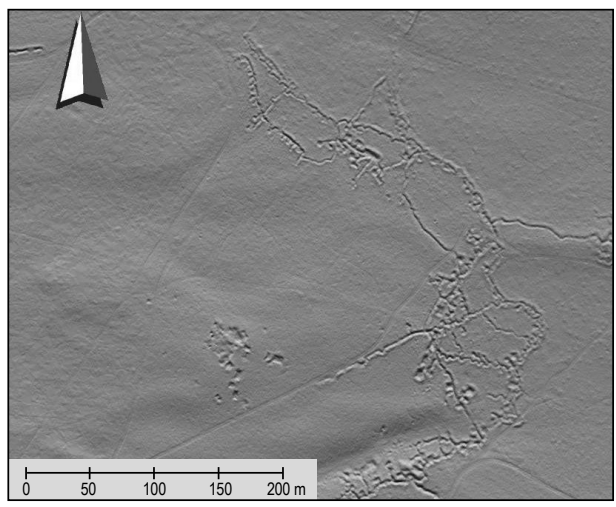

a) cieniowanie zboczy (ang. hill-shading)

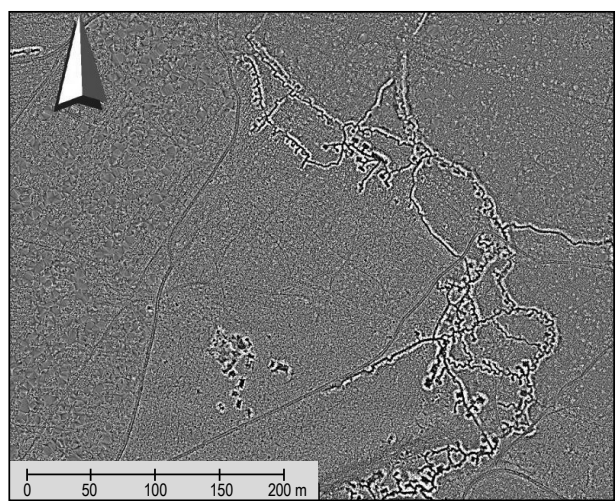

c) nachylenie zboczy (ang. slope)

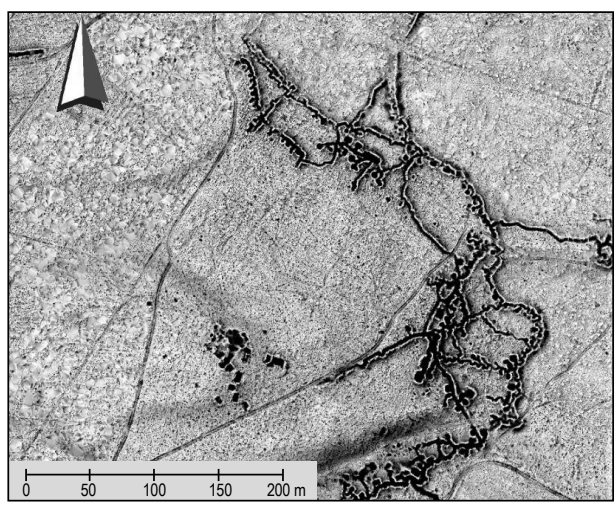

e) wspótczynnik widoku nieba (ang. sky-view factor)

Ryc. 10. Pakosław, woj. mazowieckie. Fortyfikacje polowe - wizualizacja na bazie pomiarów ALS oraz przetworzeń geodanych. Żródto: UKSW. Oprac. R. Zapłata ${ }^{31}$

31 Przetworzenia i wizualizacje przygotowano w oparciu o programy GlobalMapper (a) oraz Relief Visualization Toolbox v. 1.1 (b-e). Wizualizacje i przetworzenia wykonane na danych ALS pozyskanych w ramach pomiarów dokonanych w okresie wiosennym na potrzeby badania zasobów zabytkowych. Wykonawca: MGGP Aero (gęstość skanowania $6 \mathrm{pkt} / \mathrm{m}^{2}$ ). 

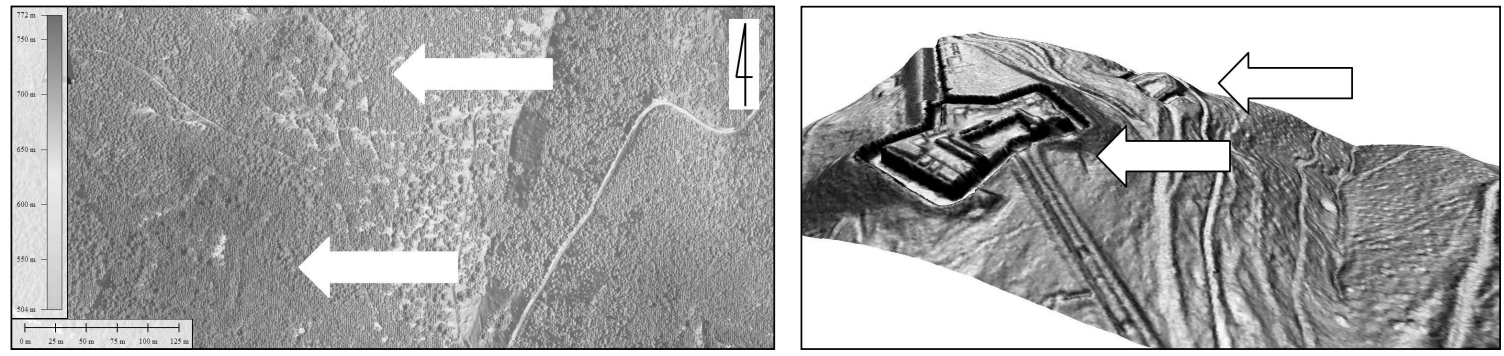

Ryc. 11. Srebrna Góra, woj. dolnośląskie. Wizualizacja Fortu Chochoł Mały oraz lunety na Chochole Małym (fleszy) zabytkowej Twierdzy Srebrna Góra, znajdujących się na terenie zalesionym. NMPT - wizualizacja stopnia zalesienia terenu oraz obiektu - u góry; mapa cieniowanej rzeźby terenu (obiektów) NMT - na dole.

Źródło: MGGP Aero / ISOK. Oprac. R. Zapłata

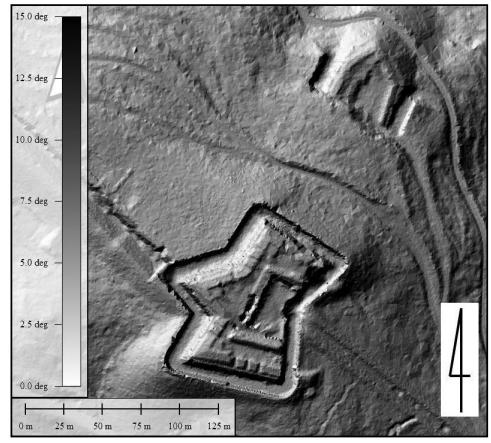

a) cieniowanie zboczy (ang. hill-shading)

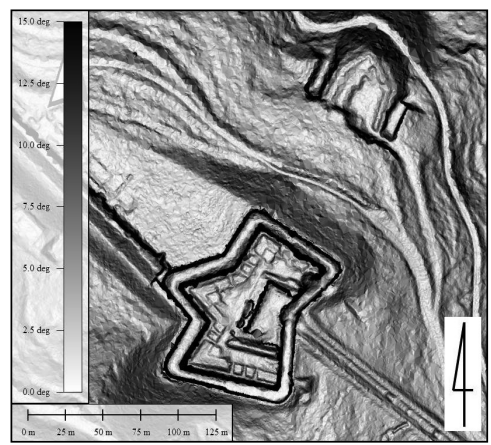

d) nachylenie zboczy (ang. slope)

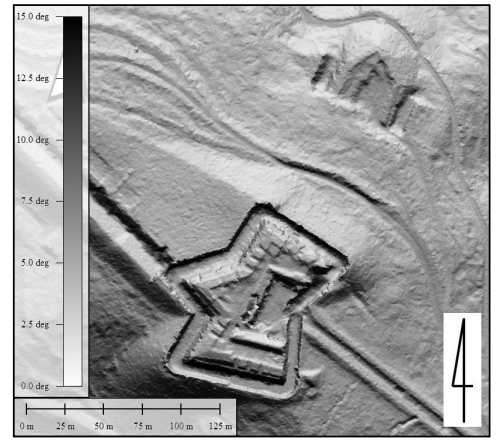

b) wielokierunkowe cieniowanie zboczy (ang. multidirectional hill-shading)

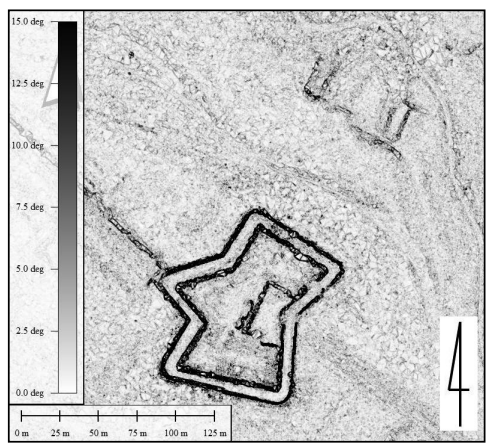

e) lokalny model rzeźby terenu (ang. local relief model)

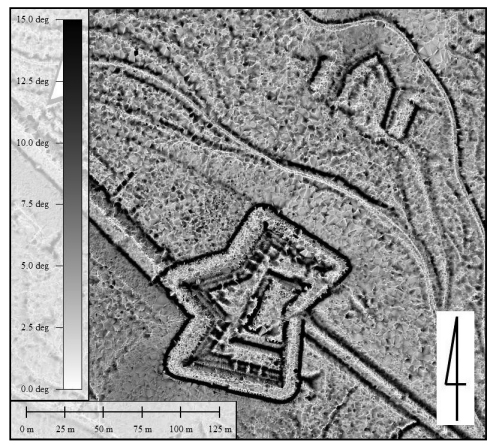

c) otwarcie (ang. openess)

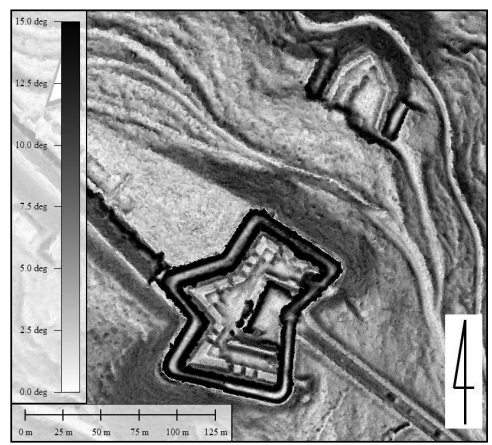

f) wspótczynnik widoku nieba (ang. sky-view factor)

Ryc. 12. Srebrna Góra, woj. dolnośląskie - Fort Chochoł Mały oraz luneta na Chochole Małym (flesza) zabytkowej Twierdzy Srebrna Góra. Wizualizacje fortyfikacji stałych i otoczenia na bazie pomiarów ALS oraz następujących przetworzeń geodanych. Źródto: MGGP Aero / ISOK. Oprac. R. Zapłata ${ }^{32}$

32 Przetworzenia i wizualizacje przygotowano w oparciu o programy GlobalMapper (a) oraz Relief Visualization Toolbox v. 1.1 (b-f). 


\section{Czwarty wymiar ALS - potencjał i możliwości}

Detekcji i inwentaryzacji zabytkowych fortyfikacji w oparciu o technologię ALS dokonujemy przede wszystkim na podstawie pomiaru przestrzennego, a następnie przetworzenia geodanych (co omówiliśmy przekrojowo powyżej), jednak w ostatnich latach na znaczeniu zyskuje również tzw. czwarty wymiar skanowania laserowego, a więc pomiar i rejestracja intensywności odbicia powracającej wiązki lasera ${ }^{33}$. Intensywność odbicia wiązki lasera określana jest $\mathrm{w}$ literaturze przedmiotu jako współczynnik czy też wartość energii odbitej od powierzchni mierzonej, która wyrażana jest $\mathrm{w}$ postaci wartości liczbowej lub procentowej jako jednostka niemianowana. Omawiana reakcja dotyczy zetknięcia (interakcji) wysyłanego sygnału urządzenia (skanera) z różnorodnymi powierzchniami (obiektami), które z uwagi na rodzaj tekstury oraz inne właściwości stwarzają odmienne warunki odbijania się światha, ale i jego pochłaniania oraz rozpraszania ${ }^{34}$. Rejestracja i analiza pomiaru intensywności odbicia stwarzają możliwość uzupełniającego rozróżniania i klasyfikacji pokrycia terenu oraz jego powierzchni, co jest efektem np. odmiennej wilgotności, temperatury itp. Czynnikami mającymi wpływ na wartość intensywności odbicia powracającej wiązki lasera są również kąt padania promienia, długość fali oraz odległość pomiędzy emiterem a obiektem mierzonym (szerzej na ten temat w cytowanej literaturze przedmiotu $)^{35}$.

Zjawisko to znajduje również zastosowanie w odniesieniu do detekcji obiektów zabytkowych, zwłaszcza na terenach otwartych, gdzie

\footnotetext{
33 K. Challis, A.J. Howard, The Role of Lidar Intensity Data in Interpreting Environmental and Cultural Archaeological Landscapes, w: Interpreting Archaeological Topography. Airborne Laser Scanning, 3D Data and Ground Observation, ed. R.S. Opitz, D.C. Cowley, Oxford-0akville 2013, s. 161-170.

${ }^{34} \mathrm{~A}$. Warchoł, Wykorzystanie wskaźnika intensywności odbicia w procesie pozyskiwania sieci drogowej z danych lidarowych, „Archiwum Fotogrametrii, Kartografii i Teledetekcji”, 20, 2009, s. 433-444; tenże, Aplikacja współczynnika intensywności do klasyfikacji pokrycia terenu na obszarach rolniczych, „Infrastruktura i Ekologia Terenów Wiejskich", 6, 2010, s. 59-66.

35 D.S. Boyd, R.A. Hill, Validation of Airborne LiDAR Intensity Values From a Forested Landscape Using Hymap Data: Preliminary Analyses, „IAPRS”, 36 (3 / W52), 2007, s. 71-76 (http://www.isprs.org/ proceedings/XXXVI/3-W52/final_papers/Boyd_2007.pdf, dostęp: 31 grud-
} nia 2014). w oparciu o tzw. wyróżniki wegetacyjne, wilgotnościowe czy temperaturowe istnieje możliwość wskazywania potencjalnych podziemnych i napowierzchniowych struktur zabytkowych. Schemat zjawiska oraz procesu rozpoznawania obiektów wraz z przykładem pozytywnej weryfikacji historycznej zabudowy w oparciu o wartość intensywności odbicia powracającej wiązki lasera ilustruje rycina 13.

Kolejnym krokiem rozwijającym możliwości dokładniejszego analizowania terenu, a zarazem jego zróżnicowania pod względem np. wilgotności, pokrycia szatą roślinną, wynikającego m.in. z zalegających pod powierzchnią pozostałości założeń militarnych, jest włączenie do procedury badawczej skanerów o kilku długościach fal, wykonujących pomiar jednocześnie. Jak już zostało wspomniane, wpływ na wartość współczynnika odbicia ma również długość emitowanej fali elektromagnetycznej $j^{36}$. W zależności od tego parametru uzyskujemy odmienne współczynniki odbicia dla różnych powierzchni, ale i dla tych samych rodzajów powierzchni (obiektów). Ponieważ odmienne długości fal powodują zróżnicowane reakcje z tymi samymi, a także różnorodnymi powierzchniami, pojawia się szansa na dodatkową penetracjęterenuizasobówzabytkowych.Przykładowo fale o długości 532, 905, 1064 czy $1550 \mathrm{~nm}$ w zetknięciu z np. asfaltem, cementem czy ziemią dają odmienne wartości refleksyjności względnej dla każdego z materiałów (ryc. 13c-d) $)^{37}$.

Takie możliwości stwarza m.in. zastosowanie skanerów następnej - nowej generacji, co z uwagi na innowacyjność technologii ${ }^{38}$ należy traktować

36 R.N. Clark i in., USGS Digital Spectral Library, [b.m.w.] 2003 (http:// pubs.usgs.gov/of/2003/ofr-03-395/ofr-03-395.html, dostęp: 31 grudnia 2014); M. Bednjanec, Calibration of ALS Intensity Data, Stockholm 2011, s. 21 (http://kth.diva-portal.org/smash/get/diva2:438876/FUL LTEXT01.pdf, dostęp: 31 grudnia 2014).

37 Za: A.M. Baldridge i in., The ASTER Spectral Library Version 2.0, „Remote Sensing of Environment”, 113, 2009, s. 711-715 (http:// speclib.jpl.nasa.gov/downloads/2009-Baldridge.pdf, dostęp: 31 grudnia 2014).

38 Optech Announces Titan, the World's First Multispectral Airborne Lidar Sensor (http://www.teledyneoptech.com/wp-content/uploads/ Optech-News-Release_Titan_201412011.pdf, dostęp: 31 grudnia 2014); Optech Titan Multispectral Lidar System (http://www.geo -matching.com/upload/179-2585-3703.PDF, dostęp: 31 grudnia 2014); Optech Titan: jeden skaner, trzy lasery (http://geoforum.pl/ ? page $=$ news\&id $=18876 \&$ link $=$ optech-titan-jeden-skaner-trzy -lasery, dostęp: 31 grudnia 2014). 


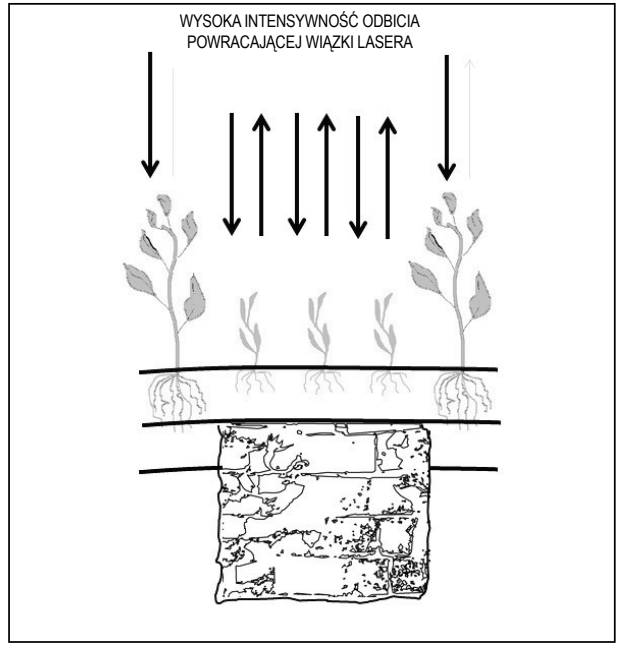

a

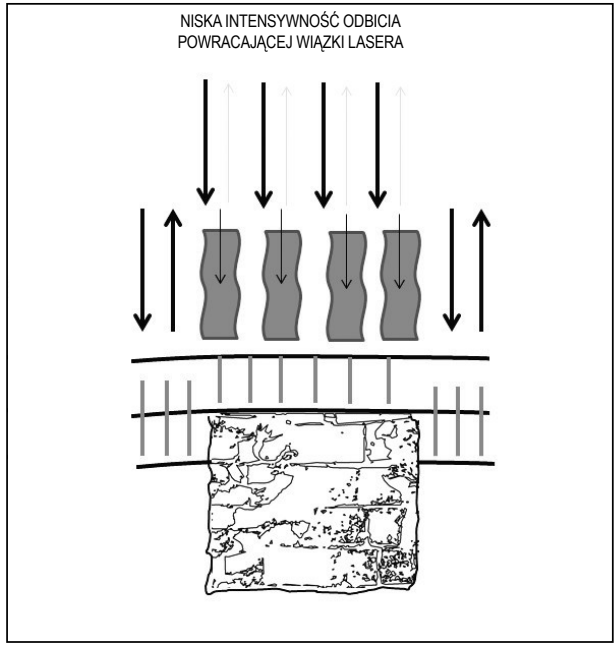

b

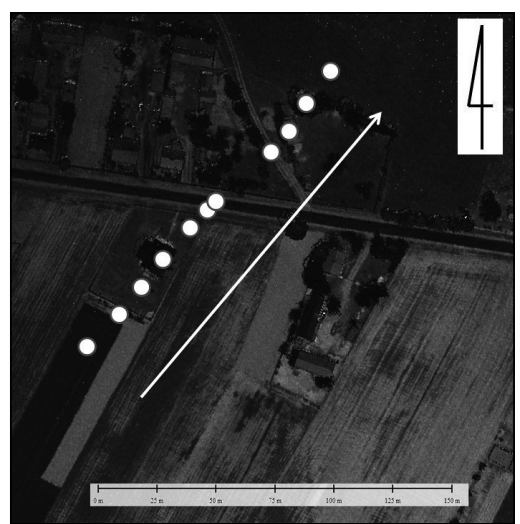

c

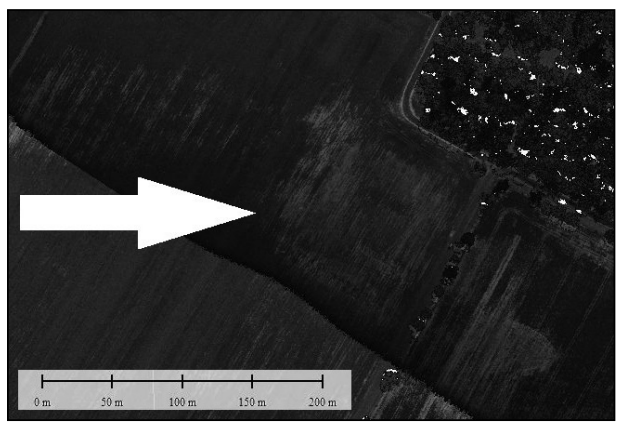

e

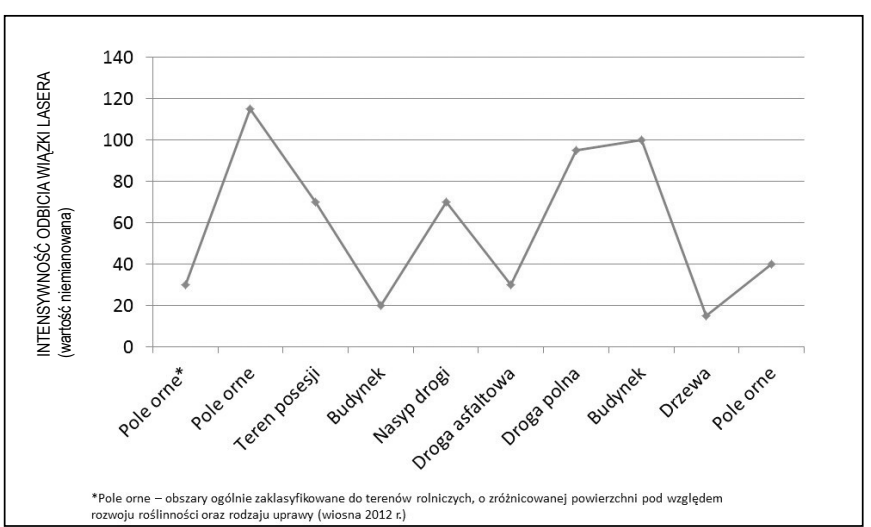

$d$

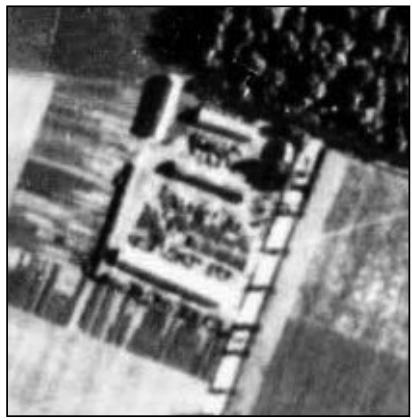

f

Ryc. 13. Intensywność odbicia powracającej wiązki lasera. Schemat reakcji światta lasera dla zróżnicowanego podłoża (powierzchni): a) roślinność / powierzchnia sucha, b) powierzchnia wilgotna; c, d) przykład zróżnicowanych wartości intensywności odbicia lasera od poszczególnych powierzchni; e, f) przykład różnic wartości intensywności odbicia powracającej wiązki lasera - pozostałości historycznej zabudowy w miejscowości Pakosław, woj. mazowieckie (archiwalne zdjęcie lotnicze z 1944 r.).

Źródto: UKSW/NARA, za: R. Zapłata, „Nieinwazyjne metody” 


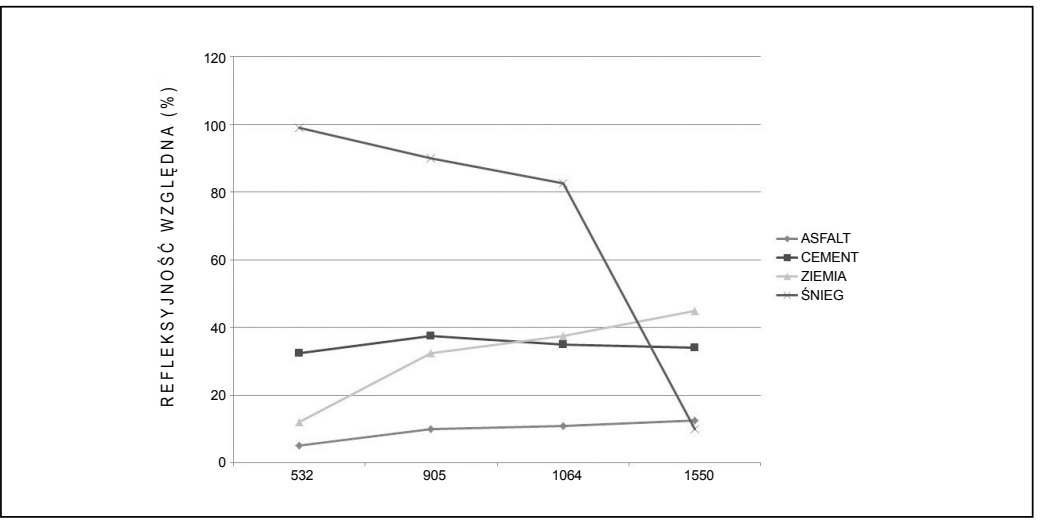

Ryc. 14. Wartości refleksyjności względnej poszczególnych długości fali dla różnych materiatów. 532, 905, 1064 i $1550 \mathrm{~nm}$ - częstotliwości powszechnie stosowane w skanowaniu laserowym. Za: R. Zapłata, „Nieinwazyjne metody”, na podstawie: A.M. Baldridge i in., ,The ASTER”

jako kolejny element rozwoju i aplikowania technologii ALS do badań nad zabytkowymi fortyfikacjami.

\section{Podsumowanie}

Dokładność pomiarów ALS wraz z przywołanymi przetworzeniami geodanych, a także tzw. czwarty wymiar stwarzają możliwość: rozpoznawania potencjalnych obiektów militarnych z własną rzeźbą krajobrazową (wysokościową), zwłaszcza na terenach zalesionych; rozpoznawania potencjalnych obiektów militarnych o śladowo zachowanej lub niezachowanej rzeźbie wysokościowej, na podstawie danych o intensywności odbicia wiązki lasera (wyróżniki wegetacyjne, wilgotnościowe, glebowe itp.). Przywołane przykłady zróżnicowanych przetworzeń skłaniają do wniosku, że konieczne jest sięganie po kilka wzajemnie uzupełniających się przetworzeń danych ALS, które m.in. w zależności od rodzaju obiektów dają lepsze wyniki badawcze. Zaprezentowany w tekście zestaw przykładów wykonanych przetworzeń i ich analiz, jak również wysoka dokładność pomiarów ALS potwierdzają zasadność detekcji i badania takich elementów zabytkowych fortyfikacji, które obecnie charakteryzują deniwelacje wysokościowe w terenie rzędu nawet kilkunastu czy kilku centymetrów, jak pozostałości samych fortów, twierdz, a także elementów założeń militarnych, takich jak: urządzenia przeciwsztur- mowe, szańce, wilcze doły, rowy strzeleckie, stanowiska przeciwogniowe; pozostałości pokojowych magazynów amunicji, redut; przedpola (np. linie ciągłych przeszkód, punkty oporu, kawerny, pasy zasieków); konstrukcje ziemne (np. wały, fosy); nieukończone forty i elementy fortyfikacji; inne fortyfikacje polowe (np. palisady, blokhauzy) czy elementy związane z rozbudowami mobilizacyjnymi.

Podsumowując niewątpliwy potencjał ALS w badaniu fortyfikacji nowożytnych, podkreślmy raz jeszcze kilka zagadnień, które wymagają uwzględnienia przy korzystaniu z danych ALS (w tym danych ISOK), wskazując pokrótce pewne rozwiązania na przyszłość. Przywołana w tekście niska gęstość i zróżnicowany rozkład punktów na powierzchni terenu (czy też na powierzchni obiektów zabytkowych) w zależności od potrzeb konserwatorsko-badawczych mogaz skłaniać np. do ponownego wykonania pomiarów ALS, a zarazem zróżnicowanego analizowania całych powierzchni, np. terenów zalesionych. W wielu sytuacjach do opracowania poprawniejszego odwzorowania powierzchni terenu i obiektów zabytkowych konieczna wydaje się klasyfikacja chmury punktów czy też reklasyfikacja o charakterze nadzorowanym (manualna), a nie automatyczna. Pośród wskazanych w tekście postulatów badawczych bez wątpienia należy przywołać włączanie do badań skanerów o kilku długościach fal. 
Omówione wyżej wybrane zagadnienia laserowych pomiarów obiektów zabytkowych odnoszą się do rejestracji powierzchni odsłoniętych struktur stojących, a także powierzchni terenu, która w mniejszym lub większym stopniu stanowi pozostałości zniszczonych obiektów. Oddzielnym, ale $\mathrm{i}$ istotnym zagadnieniem metodyki badawczej jest wykonywanie naziemnych pomiarów laserowych, zwłaszcza obiektów odsłanianych w wyniku badań archeologiczno-architektonicznych, co wykracza poza ramy niniejszego tekstu. Zaprezentowanie tu metod przetwarzania i wizualizacji danych ALS miało na celu m.in. przybliżenie i omówienie wybranych kwestii metodycznych w odniesieniu do tytułowych zagadnień, nie wyczerpując jednak wszystkich możliwych sposobów opracowywania tzw. chmury punktów, do których należy również zaliczyć stosowanie skal kolorowych, metod zmiany sposobu oświetlania obiektów, w tym barwy czy nasycenia. Warto podkreślić, że w procesie analitycznym generowanych na bazie danych ALS modeli cyfrowych, jak również samej chmury punktów znaczące jest również uwzględnienie perspektywy trójwymiarowej (obok ilustrowanej dwuwymiarowej) w czasie rzeczywistym, co oferuje szereg programów komputerowych (ryc. 11). Tak konstruowana interaktywna praca z danymi stwarza dodatkową możliwość analizy i interpretacji obiektów zabytkowych.

Podsumowując, warto raz jeszcze podkreślić omówione zagadnienia, które wyznaczają kolej- ne kroki w zakresie rozwoju metodyki badawczej fortyfikacji nowożytnych: wykorzystanie danych ALS w poszukiwaniu i inwentaryzacji fortyfikacji polowych, zastosowanie danych TLS $\mathrm{w}$ analizowaniu i diagnozowaniu obiektów typu architectura militaris wraz z otoczeniem, stosowanie różnego rodzaju przetworzeń i wizualizacji geodanych poszerzających możliwości analityczno-interpretacyjne, włączenie do prac analizy intensywności odbicia wiązki lasera, terenowa weryfikacja (nieinwazyjna, ale i inwazyjna) wskazań potencjalnych obiektów oraz danych ALS, uzupełniające pomiary laserowe (lotnicze lub naziemne) obszarów o niskiej gęstości punktów, stosowanie skanerów o kilku długościach fal (np. trzech).

Potencjał danych ALS to również cały szereg zastosowań, których omówienie wykracza poza ramy niniejszego tekstu, a które dotyczą m.in.: możliwości dodatkowego rozpoznania wartości architektonicznych, krajobrazowych i kulturowych architectura militaris; generowania modeli cyfrowych obiektów zniszczonych, nieistniejących, a następnie modelowania i symulacji zjawisk z przeszłości, analizowania i monitorowania zniszczeń, postępujących zmian - innymi słowy modelowania procesów destrukcyjnych (np. osuwiskowych czy zalewowych) czy w końcu wykorzystywania tego typu danych w konsultacjach społecznych związanych z procesami rewitalizacyjnymi, adaptacyjnymi czy rekonstrukcyjnymi. 


\section{Bibliografia}

Źródła ilustracji

Narodowe Archiwum Cyfrowe, Zdjęcie archiwalne Umocnienia wojskowe w okolicach Tarnobrzega-okopy z lat 1914-1915.

National Archives and Record Administration / Archiwa Narodowe Stanów Zjednoczonych, Zdjęcie archiwalne Warszawy z 1944 r.

\section{Źródła kartograficzne}

Mapa topograficzna Warszawa-Żoliborz, skala 1:25 000, Pas 39, Słup 32 G (3932 G), Wojskowy Instytut Geograficzny, 1934 (http:// igrek.amzp.pl/, dostęp: 31 grudnia 2014).

\section{Literatura przedmiotu}

Antoszewski M., Ostrowski W., Lotniczy skaning laserowy (projekt ISOK) w ochronie zespotów fortyfikacji nowszej, w: Fortyfikacje nowozytne w Polsce - badania, realizacje, projekty. Zagospodarowanie do wspótczesnych funkcji, red. L. Narębski, Toruń 2013.

Bakuła K., Ostrowski W., Zapłata R., Automatyzacja w procesie detekcji obiektów archeologicznych $z$ danych ALS, „Folia Praehistorica Posnaniensia”, 19, 2014.

Baldridge A.M. i in., The ASTER Spectral Library Version 2.0, „Remote Sensing of Environment", 113, 2009, s. 711-715 (http://speclib.jpl.nasa.gov/downloads/2009-Baldridge. pdf, dostęp: 31 grudnia 2014).

Banaszek Ł., Rączkowski W., Potencjat danych ALS w badaniach archeologicznych, w: Podręcznik dla uczestników szkoleń z wykorzystania produktów LiDAR, Kraków 2014, s. 192-200 (http://szkolenialidar.gugik.gov. $\mathrm{pl} /$ szkolenia/materialy-szkoleniowe/podre cznik/, dostęp: 31 grudnia 2014).

Barełkowska K., Dziedzictwo architectura militaris i jego spoteczna percepcja, w: Zamki, grody, ruiny. Waloryzacja i ochrona, red. M. Lewicka, Warszawa-Białystok 2009, s. 443 454.

Bednjanec M., Calibration of ALS Intensity Data, Stockholm 2011 (http://kth.diva-por tal.org/smash/get/diva2:438876/FULL TEXT01.pdf, dostęp: 31 grudnia 2014).
Uniwersytet Kardynała Stefana Wyszyńskiego / National Archives and Record Administration, Zdjęcie archiwalne okolic Pakosławia, woj. mazowieckie z 1944 r.

Topographische Karte, skala 1:25 000, (Meßtischblatt), Neurode, 5465 (3189), 1937 (Archiwum Map Zachodniej Polski: http://igrek.amzp.pl/; http://mapy.amzp.pl/, dostęp: 31 grudnia 2014).

Bennett R. i in., A comparison of Visualization Techniques for Models Created from Airborne Laser Scanned Data, „Archaeological Prospection”, 19, 2012, s. 41-48.

Bewley R.H., Crutchley S., Shell C.A., New Light on an Ancient Landscape: Lidar Survey in the Stonehenge World Heritage Site, "Antiquity", 79, 2005, s. 636-647.

Biesiekierski K., Kleczke K., Rewieński M., Fortyfikacja polowa, Oświęcim 2014 (Warszawa 1929).

Blanco-Rotea R. i in., Using Airborne Laser Scanning and Historical Aerial Photos to Identify Modern Age Fortifications in the Minhovalley, Northwest Iberia, [b.m.w.] 2014 (http://digit al.csic.es/bitstream/10261/101376/3/2014_ Blanco-Rotea_etal-UISPP-BaixoMinho.pdf, dostęp: 31 grudnia 2014).

Bogdanowski J., Krajobraz warowny XIX/XX w. Dzieje i rewaloryzacja, Kraków 1993.

Bogdanowski J. i in., Maty stownik terminologiczny dawnej architektury obronnej w Polsce, Kraków 1988.

Borkowski A. i in., Wykorzystanie danych skaningu laserowego do modelowania $3 D$ fortów obronnych na przyktadzie Fortu Prusy w Nysie, „Architektura Krajobrazu”, 4, 2013, s. 3041.

Borkowski A., Jóźków G., Ocena doktadności modelu 3D zbudowanego na podstawie danych skaningu laserowego - przyktad zamku 
Piastów Ślaskich w Brzegu, „Archiwum Fotogrametrii, Kartografii i Teledetekcji”, 23, 2012, s. 37-47.

Boyd D.S., Hill R.A., Validation of Airborne LiDAR Intensity Values From a Forested Landscape Using Hymap Data: Preliminary Analyses, „IAPRS”, 36 (3/W52), 2007, s. 71-76 (http://www.isprs.org/proceedings/XXXVI/ 3-W52/final_papers/Boyd_2007.pdf, dostęp: 31 grudnia 2014).

Challis K., Forlin P., Kincey M., A Generic Toolkit for the Visualization of Archaeological Features on Airborne LiDAR Elevation Data, „Archaeological Prospection”, 18 (4), 2011, s. 279-289.

Challis K., Howard A.J., The Role of Lidar Intensity Data in Interpreting Environmental and Cultural Archaeological Landscapes, w: Interpreting Archaeological Topography. Airborne Laser Scanning, 3D Data and Ground Observation, ed. R.S. Opitz, D.C. Cowley, Oxford-Oakville 2013, s. 161-170.

Clark R.N. i in., USGS Digital Spectral Library, [b.m.w.] 2003 (http://pubs.usgs.gov/ of/2003/ofr-03-395/ofr-03-395.html, dostęp: 31 grudnia 2014).

Crutchle S., Crow P., The Light Fantastic. Using Airborne Lidar in Archaeological Survey, „International Archives of the Photogrammetry, Remote Sensing and Spatial Information Sciences", 38, 7B, 2010, s. 160-164 (http://www.isprs.org/proceedings/XXXVIII/ part7/b/pdf/160_XXXVIII-part7B.pdf, dostęp: 31 grudnia 2014).

Devereux B.J., Amable G.S., Crow P., Visualisation of LiDAR Terrain Models for Archaeological Feature Detection, „Antiquity”, 82, 2008, s. 470-479.

Doneus M., Openness as Visualization Technique for Interpretative Mapping of Airborne Lidar Derived Digital Terrain Models, „Remote Sensing", 5 (12), 2013, s. 6427-6442.

Doneus M., Briese C., Full-Waveform Airborne Laser Scanning as a Tool for Archaeological Reconnaissance, w: From Space to Place. Proceedings of the $2^{\text {nd }}$ International Workshop on Remote Sensing in Archaeology, CNR, Rome, Italy, 4-7 December, ed. S. Campana,
M. Forte, Oxford 2006, s. 99-105 (http:// www.ipf.tuwien.ac.at/publications/2006/ Doneus_Briese_ROME.pdf,dostęp:31 grudnia 2014).

Dybaś B., Fortece Rzeczypospolitej. Studium $z$ dziejów budowy fortyfikacji statych w państwie polsko-litewskim w XVII wieku, Toruń 1998.

Dybaś B., Polskie fortyfikacje state w epoce nowożytnej (1500-1795), w: Studia z dziejów polskiej techniki wojskowej od XVI do XX wieku, red. J. Wojtasik, Warszawa 2001, s. 9-93.

Feld-pionierdienst aller Waffen, Berlin 1911.

Fortyfikacja, t. 6: Ochrona i konserwacja architektury obronnej, red. M. Lewicka-Cempa, Warszawa 1999.

Fortyfikacje nowożytne w Polsce - badania, realizacje, projekty. Zagospodarowanie do wspótczesnych funkcji, red. L. Narębski, Toruń 2013.

Guth P.L., Terrain Organization Calculated From Digital Elevation Models, w: Concepts and Modelling in Geomorphology: International Perspectives, ed. I.S. Evans i in., Tokyo 2003, s. 199-220.

Hesse R., Detecting Former Field Systems with Airborne LIDAR - An Overview of Current Methods, poster, [b.m.w.] 2012 (http://www. academia.edu/1941481/Detecting_former_ field_systems_with_airborne_LIDAR_ _an_overview_of_current_methods, dostęp: 31 grudnia 2014).

Hesse R., Extraction of Archaeological Features From High-Resolution LIDAR Data, w: $14^{\text {th }}$ International Congress „Cultural Heritage and New Technologies", Vienna, 2009, [b.m.w.] 2010, s. 636-642 (http://www.academia.edu/ 1045403/Extraction_of_archaeological_fea tures_from_high-resolution_LIDAR_data, dostęp: 31 grudnia 2014).

Hesse R., Lidar-Derived Local Relief Models A New Tool for Archaeological Prospection, „Archaeological Prospection”, 17, 2010, s. 6772.

Interpreting Archaeological Topography. Airborne Laser Scanning, 3D Data and Ground Observation, ed. R.S. Opitz, D.C. Cowley, Oxford-Oakville 2013. 
Jennees J., Topographic Position Index (TPI) v. 1.2, [b.m.w.] 2006 (http://www.jennes sent.com/downloads/TPI_Documentation _online.pdf, dostęp: 31 grudnia 2014).

Kasprzak M., Traczyk A., Geomorfometria granitowej cześsi Karkonoszy, „Landform Analysis", 13, 2010, s. 33-46.

Kokalj Ž., Zakšek K., Oštir K., Visualizations of Lidar Derived Relief Models, w: Interpreting Archaeological Topography - Airborne Laser Scanning, Aerial Photographs and Ground Observation, ed. R.S. Opitz, D.C. Cowley, Oxford 2013, s. 100-114.

Kozłowska I., Szczecińskie fortyfikacje nowożytne. Rola fortyfikacji nowożytnych $w$ ksztattowaniu uktadu przestrzennego miasta Szczecina oraz wptyw analizy historycznej na wspótczesne dziatania projektowe $i$ zakres ochrony konserwatorskiej, Szczecin 2007, rozprawa doktorska (http://pbc.gda.pl/dlibra/doccontent?id= 8063\&from=FBC, dostęp: 31 grudnia 2014).

Królikowski L., Twierdza Warszawa, Warszawa 2002.

Kurczyński Z., Bakuła K., The Selection of Aerial Laser Scanning Parameters for Countrywide Digital Elevation Model Creation, „SGEM2013 Conference Proceedings”, 2, 2013, s. 695-702.

Laserowi odkrywcy. Nieinwazyjne badanie i dokumentowanie obiektów archeologicznych $i$ historycznych województwa świętokrzyskiego, red. R. Zapłata, B. Szady, K. Stereńczak, Stare Babice 2014.

Legut-Pintal M., LiDAR w badaniach nad średniowiecznymi fortyfikacjami i siedzibami obronnymi. Przyktad zatożen obronnych księstwa biskupów wroctawskich, [b.m.w.] 2012 (http://www.academia.edu/3102476/LiDAR _w_badaniach_nad_sredniowiecznymi_for tyfikacjami_i_siedzibami_obronnymi._Przy klad_zalozen_obronnych_ksiestwa_biskup ow_wroclawskich, dostęp: 31 grudnia 2014).

Loisios D., Tzelepis N., Nakos B., A Methodology for Creating Analytical Hill-Shading by Combining Different Lighting Directions, w: Proceedings of the 23rd International Cartographic Conference, Moscow, August 2007, Moscow 2007 (http://www.mountaincartography.org/ publications/papers/ica_cmc_sessions/5_ Moscow_Session_Mountain_Carto/moscow _loisios.pdf, dostęp: 31 grudnia 2014).

Molski P., Cechy fortyfikacji nowszej a metody waloryzacji konserwatorskiej, w: Prace naukowe / Wydziat Architektury Politechniki Warszawskiej, t. 2, Warszawa 2002.

Molski P., Ochrona i zagospodarowanie wybranych zespotów fortyfikacji nowszej w Polsce, Warszawa 2007.

Nowak T.M., Badania nad historia techniki wojennej $w$ Polsce: stan i perspektywy rozwo$j u$, „Kwartalnik Historii Nauki i Techniki”, 22 (2), 1977, s. 295-310.

Nowakowski J., Airborne Laser Scanning (ALS) $w$ polskiej archeologii. Próby, doświadczenia, wyniki, Poznań 2010 (referat wygłoszony na „XIX Konferencji Sprawozdawczej. Badania archeologiczne na Nizinie Wielkopolsko-Kujawskiej w latach 2008-2009”).

Omilanowska M., Defortyfikacja Gdańska na tle przeksztatceń miast niemieckich $w X I X w$, „Biuletyn Historii Sztuki”, 72, 2010, s. 293334 (http://archiv.ub.uni-heidelberg.de/art dok/2032/1/Omilanowska_Defortyfikacja _Gdanska_na_tle_przeksztalcen_miast_niemie ckich_2010.pdf, dostęp: 31 grudnia 2014). Optech Announces Titan, the World's First Multispectral Airborne Lidar Sensor (http://www. teledyneoptech.com/wp-content/uploads/ Optech-News-Release_Titan_201412011. pdf, dostęp: 31 grudnia 2014).

Optech Titan Multispectral Lidar System (http:// www.geo-matching.com/upload/179-2585 -3703.PDF, dostęp: 31 grudnia 2014).

Ostrowski W., Bakuła K., Zapłata R., A New Look at Historic Fortifications - Medieval Castles and Airborne Laser Scanning, w: Anthropology, Archaeology, History, Philosophy. Conference Proceedings - SGEM, International Multidisciplinary Scientific GeoConference SGEM - Bulgaria, Albena, Albena 2014, s. 307-314.

Ostrowski W., Zawieska D., Airborne Laser Scanning and GIS Application in Protection of Cultural Landscape of Fortifications, „SGEM2014 Conference Proceedings”, 3, 2014, s. 429-436. 
Pavelka K. i in., Some Using of Airborne Laser Scanning in Archaeology, w: Towards Horizon 2020: Earth Observation and Social Perspectives, EARSeL, Symposium Proceedings, ed. R. Lasaponara, N. Masini, M. Biscione, Matera 2013, s. 849-856 (http://www.ear sel.org/symposia/2013-symposium-Matera/ pdf_proceedings/EARSeL-Symposium-2013 _14_1_pavelka.pdf, dostęp: 31 grudnia 2014).

Prądzyński I., Umocnienia polowe, Warszawa 1986.

Salvador I., Vitti A., Survey, Representation and Analysis of a World War I Complex Systems of Surface and Underground Fortifications in the Gresta Valley - Italy, „International Archives of the Photogrammetry, Remote Sensing and Spatial Information Sciences", 38 (5/W16), 2011, s. 319-325 (http://www. int-arch-photogramm-remote-sens-spatial -inf-sci.net/XXXVIII-5-W16/319/2011/ isprsarchives-XXXVIII-5-W16-319-2011. pdf, dostęp: 31 grudnia 2014).

Sławik Ł., Zapłata R., LIDAR $w$ archeologii zagadnienia wprowadzajace, w: Digitalizacja dziedzictwa archeologicznego - wybrane zagadnienia, red. R. Zapłata, Lublin 2011, s. 207-232 (http://wiedzaiedukacja.eu/wp -content/uploads/2012/02/Digitalizacja \%20dziedzictwa\%20archeologicznego\%20 \%5Bred\%5D\%20Rafal\%20Zaplata.pdf, dostęp: 31 grudnia 2014).

Sławik Ł., Zapłata R., LIDAR w badaniach archeologicznych, Warszawa 2010 (prezentacja na konferencji „Metody geofizyczne w archeologii polskiej").

Stereńczak K., Lotnicze skanowanie laserowe, $\mathrm{w}:$ Las $w$ rastrowym modelu danych przestrzennych, red. K. Będkowski, Warszawa 2011, s. 63-74.

Stereńczak K., Skanowanie laserowe i geomatyka, w: Laserowi odkrywcy. Nieinwazyjne badanie i dokumentowanie obiektów archeologicznych $i$ historycznych województwa świętokrzyskiego, red. R. Zapłata, B. Szady, K. Stereńczak, Stare Babice 2014, s. 92-110.

Stolzman B., Partyzantka, czyli Wojna dla ludów powstajacych najwtaściwsza, Paryż-Lipsk
1844 (http://www.google.pl/books?hl=pl\&lr $=$ lang_pl\&id=BaY_AAAAYAAJ\&oi=fnd $\& p g=P R 1 \& d q=$ okopy+wojenne\&ots $=8 \mathrm{~B} 1$ 65QYBUt\&sig=E91AsC3M2ilgPVV795Y VS8dmC4w\&redir_esc $=\mathrm{y} \# \mathrm{v}=$ onepage $\& \mathrm{q}=$ okopy $\% 20$ wojenne $\& \mathrm{f}=$ false, dostęp: 31 grudnia 2014).

Štular B. i in., Visualization of Lidar-Derived Relief Models for Detection of Archaeological Features, "Journal of Archaeological Science", 39, 2012, s. 3354-3360.

Swaryczewski A., Maty stownik terminologiczny dawnej architektury obronnej w Polsce, Kraków 1988.

Warchoł A., Aplikacja wspótczynnika intensywności do klasyfikacji pokrycia terenu na obszarach rolniczych, „Infrastruktura i Ekologia Terenów Wiejskich”, 6, 2010, s. 59-66.

Warchoł A., Wykorzystanie wskaźnika intensywności odbicia w procesie pozyskiwania sieci drogowej $z$ danych lidarowych, „Archiwum Fotogrametrii, Kartografii i Teledetekcji”, 20, 2009, s. 433-444.

Weiss A.D., Topographic Position and Landforms Analysis, [b.m.w.] 2001 (http://www.jennes sent.com/downloads/tpi-poster-tnc_18x22. pdf, dostęp: 31 grudnia 2014).

Zagajewski B., Jarocińska A., Olesiuk D., Metody i techniki badań geoinformatycznych, Warszawa 2009.

Zakšek K., Oštir K., Kokalj Z., Sky-View Factors as a Relief Visualization Technique, „Remote Sensing”, 3, 2011, s. 398-415.

Zapłata R., LIDAR $w$ archeologii. Pilotażowy projekt zastosowania lotniczego skaningu laserowego $w$ archeologii - wybrane tereny na obszarze woj. wielkopolskiego i tódzkiego, Warszawa 2010, mps przechowywany w archiwum UKSW.

Zapłata R., Nieinwazyjne metody $w$ badaniu i dokumentacji dziedzictwa kulturowego - aspekty skanowania laserowego $w$ badaniach archeologicznych i architektonicznych, Warszawa 2013.

Zapłata R., Okopy wojskowe z I wojny światowej $w$ świetle lotniczego skanowania laserowego Pakostaw, woj. mazowieckie, Warszawa 2014, poster przechowywany w archiwum UKSW.

\section{I72 Studia Geohistorica • Nr 03. 2015}


Zapłata R., Twierdza Srebrna Góra w świetle przetworzeń i wizualizacji danych ALS / ISOK - przyktad nieinwazyjnych badań zabytkowego zatożenia obronnego, Warszawa 2014, mps przechowywany w archiwum UKSW / MGGP Aero.

Zapłata R., Bakuła K., Ostrowski W., Transformation Methods and ALS-data Visualization in the Studies of Historical Charcoal Piles, w: Anthropology, Archaeology, History, Philosophy. Conference Proceedings - SGEM, International Multidisciplinary Scientific GeoConference SGEM - Bulgaria, Albena, Albena 2014, s. 417-424.

Zapłata R., Borowski M., GIS w archeologiiprzyktad prospekcji i inwentaryzacji dziedzic- twa archeologiczno-przemystowego, „Roczniki Geomatyki”, 11 (4/61), 2013, s. 103-112.

Zawieska D., Ostrowski W., Antoszewski M., Wykorzystanie danych lotniczego skaningu laserowego w metodyce badawczej zespotów fortyfikacji nowszej w Polsce, „Archiwum Fotogrametrii, Kartografii i Teledetekcji”, 25, 2013, s. 303-314 (http://ptfit.sgp.geodezja.org.pl/ wydawnictwa/kazimierz-2013/27_Zawieska _Ostrowski_Antoszewski_303_314.pdf, dostęp: 31 grudnia 2014).

Zawiła-Niedźwiecki T. i in., LIDAR $w$ leśnictwie, „Teledetekcja Środowiska”, 39, 2008, s. 59-66.

\section{Historic Defence Structures - Architectura Militaris and LiDAR. Chosen Aspects in the Methodology of Implementing Laser Scanning for the Detection and Documentation of Modern Fortifications}

\section{Summary}

In recent years, research of defence structures, including modern fortifications, has been advanced by the possibility of verification and documentation of historic structures with the use of aerial laser scanning (ALS). The potential of those state-of-the-art methods is more and more often noticed in literature. Literature focuses so far on permanent fortifications and bases on generally known processing methods and visualisations of geodata, such as hill-shading. Thus, worth stressing is the potential and functionalities of ALS for research of field fortifications or destroyed, levelled and barely visible parts of military fortifications. With reference to research methodology, this article stresses the importance and potential not only of spatial analyses and ALS data, but also of their processing methods and of visualisations. The latter two, available in different formats, introduce a new element in the recognition, interpretation and documentation of modern defence structures. A separate aim of this article is to draw atten- tion to growing possibilities of the analysed technology, especially to the so called fourth dimension - registration and analysis of the intensity of reflected laser radiation.

The article analyses primarily chosen aspects of methodology connected with research and documentation of modern historic structures, based on laser scanning. It also stresses the efficacy of modern remote sensing technologies for research and protection of heritage, focusing on several important issues connected with the quality of data, their processing, analysis and interpretation and well as on the characteristic environment in which military structures are found - forested areas. Practice and experience acquired so far indicate that after an introductory period of implementing such methods, certain problems connected with the acquisition of data should be pointed out, along with several important research postulates connected with the usage and improvement of hitherto applied research practice. 
The article consists of four main sections: introduction, a section devoted to historic fortifications, technology of laser scanning and different kinds of data processing, and summary. The subject matter is referred to in the light of literature and of own research results, which include analyses of fortifications from the vicinity of Pakosław in Mazovia and of the Srebrna Góra Fortress in Lower Silesia.

Research work funded by the Ministry of Science and Higher Education under the "National Programme for the Development of $\mathrm{Hu}$ manities" in 2012-2015.

Słowa kluczowe: architectura militaris, fortyfikacje nowożytne, skanowanie laserowe, geoinformacja

Keywords: architectura militaris, modern fortifications, airborne laser scanning, GIS

dr Rafał Zapłata - adiunkt w Zakładzie Konserwacji Zabytków i Ochrony Krajobrazu Instytutu Historii Sztuki Wydziału Nauk Historycznych i Społecznych Uniwersytetu Kardynała Stefana Wyszyńskiego w Warszawie. Zainteresowania badawcze: zastosowanie metod nieinwazyjnych i technologii cyfrowych w ochronie, badaniu, dokumentacji i promocji dziedzictwa kulturowego. Członek m.in. ICOMOS Polska i Stowarzyszenia Konserwatorów Zabytków (e-mail: rafalzaplata@poczta.onet.pl) 